\title{
Čas za reformo Zoisovega štipendiranja
}

Mirt Nagy*

Piran

Povzetek: V prispevku sta predstavljena zgodovina razvoja štipendiranja nadarjenih in razvoj meril ter kriterijev za dodelitev štipendij od začetkov štipendiranja nadarjenih do sprememb leta 2008, ko se je začel uporabljati nov zakon o štipendiranju. Navedene so nekatere bistvene pomanjkljivosti sedanje ureditve podeljevanja Zoisovih štipendij, kot izhajajo iz veljavnega zakona o štipendiranju, in predlog potrebnih izboljšav sistema štipendiranja, s katerimi bi Zoisove štipendije dobile večjo vlogo pri spodbujanju razvoja nadarjenih in tudi razvoja njihove kariere med in po zaključku izobraževanja.

Ključne besede: štipendiranje nadarjenih, Zoisovi štipendisti, zakon o štipendiranju, merila in kriteriji, spodbujanje razvoja nadarjenih

\section{Time for a reform of the Zois scholarships}

\author{
Mirt Nagy* \\ Piran, Slovenia
}

\begin{abstract}
The paper presents a history of development of scholarships for young talents in Slovenia. Through recent years the eligibility criteria to obtain the scholarship has changed as policy and certain characteristics have been reformed. The paper argues about stricter criteria that were implemented in recently reformed Scholarship policy act. The discussion includes a proposal for necessary improvements within the system of Zois scholarships. The described changes would assign the Zois scholarship a greater role in promoting the students' career development during and after their educational process.
\end{abstract}

Keywords: scholarships for talented, Zois scholarship, scholarship act, eligibility criteria, promoting the development of talent

\footnotetext{
*Naslov/Address: Mirt Nagy, Dantejeva 11, 6330 Piran, e-pošta: mirt.nagy@gmail.com
} 
V prispevku obravnavam problematiko meril in kriterijev pri podeljevanju štipendij za nadarjene (Zoisove štipendije), pri čemer najprej ponujam zgodovinski pregled podeljevanja štipendij od sredine šestdesetih let prejšnjega stoletja do danes in prikazujem negativne učinke trenutno veljavnih meril in kriterijev za dodelitev in ohranitev Zoisove štipendije. $\mathrm{Na}$ koncu predstavljam predlog za tako reformo Zoisovega štipendiranja, ki bo vodila do kakovostnejšega spodbujanja razvoja nadarjenih in njihove kariere.

\section{Začetki štipendiranja nadarjenih $\mathbf{v}$ Sloveniji}

Začetki štipendiranja nadarjenih segajo v leto 1966, ko je bil ustanovljen sklad za štipendiranje nadarjenih, imenovan »Milijoni za talente«. Zasluge za ustanovitev sklada so imeli psihologi na področju poklicnega usmerjanja, ki so $\mathrm{v}$ šestdesetih letih prešnjega stoletja razvili metode in pripomočke za poklicno svetovanje (vprašalnike, teste interesov, teste sposobnosti) in uvedli generacijski pristop pri poklicnem svetovanju (Makarovič, 1996). V Sloveniji, kot delu bivše Jugoslavije, je bilo poklicno usmerjanje organizirano v okviru dejavnosti zavodov za zaposlovanje in je imelo pomembno vlogo pri informiranju in poklicnem svetovanju šolski mladini. Psihologi in poklicni svetovalci so pri svojem neposrednem svetovalnem delu z učenci ugotavljali, da izbira poklica ni odvisna samo od učenca, torej njegovih interesov, šolskega uspeha in sposobnosti, ampak tudi od materialnih možnosti družine za šolanje otroka. Pogostokrat so starši zaradi slabega materialnega stanja družine, ki je bilo povezano $\mathrm{z}$ nizko izobrazbo, nasprotovali vpisu $\mathrm{v}$ zahtevnejše in dalj časa trajajoče izobraževalne programe, ker so želeli, da bi se njihov otrok čimprej izučil za poklic in se zaposlil, ali pa po končani obvezni osnovni šoli celo ostal doma na kmetiji. Šibko materialno stanje družine je bilo pri marsikaterem sposobnem učencu odločilni faktor, zaradi katerega se ni odločil za vpis na zahtevnejšo srednjo šolo, ki bi mu omogočila nadaljevanje študija na univerzi. Takšna, prekmalu zaključena izobraževalna pot pomeni izgubo za posameznika, ki ne uresniči vseh svojih potencialov, in za družbo, ki zaradi tega izgublja svoje človeške vire (slika 1). Osnovni namen sklada »Milijoni za telente« je bil spodbuditi nadarjene iz delavskih in kmečkih družin, da bi se lažje odločili za vpis v splošne srednje šole (gimnazije) kot pripravljalnice za kasnejši visokošolski študij (Kogej, 1996). Omeniti velja način izbora. Psihologi so vedeli, da se kandidati ne bodo sami prijavljali na razpis za štipendijo, saj mnogi med njimi v šoli sploh niso bili prepoznani kot nadarjeni in tudi niso bili deležni posebnih spodbud. Zato so kandidate za to štipendijo aktivno iskali na osnovi poznavanja rezultatov na testih intelektualnih sposobnosti, ki so jih za potrebe poklicnega svetovanja reševali vsi učenci zaključnih razredov osnovne šole, in poznavanja njihovih izobraževalnih namer, ki so jih zbirali z anketo o izbiri poklica. Če so odkrili učenca z izrazito visokimi dosežki na testu sposobnosti, ki se je želel vpisati na poklicno šolo, je bil to znak za intervencijo in povabilo na razgovor. Po preverjanju, da je bila taka odločitev predvsem posledica nizkega socialnoekonomskega stanja družine, je sledilo prepričevanje staršev, da dovolijo otroku vpis v zahtevnejši srednješolski program, ki omogoča nadaljevanje izobraževanja na visoki šoli, seveda ob finančni podpori v obliki štipendije.

V času delovanja sklada so učencem iz delavskih in kmečkih družin podelili več sto štipendij in jim tako pomagali doseči višjo stopnjo izobrazbe, kot bi jo dosegli brez štipendije.

NEOBIČAJNA POT

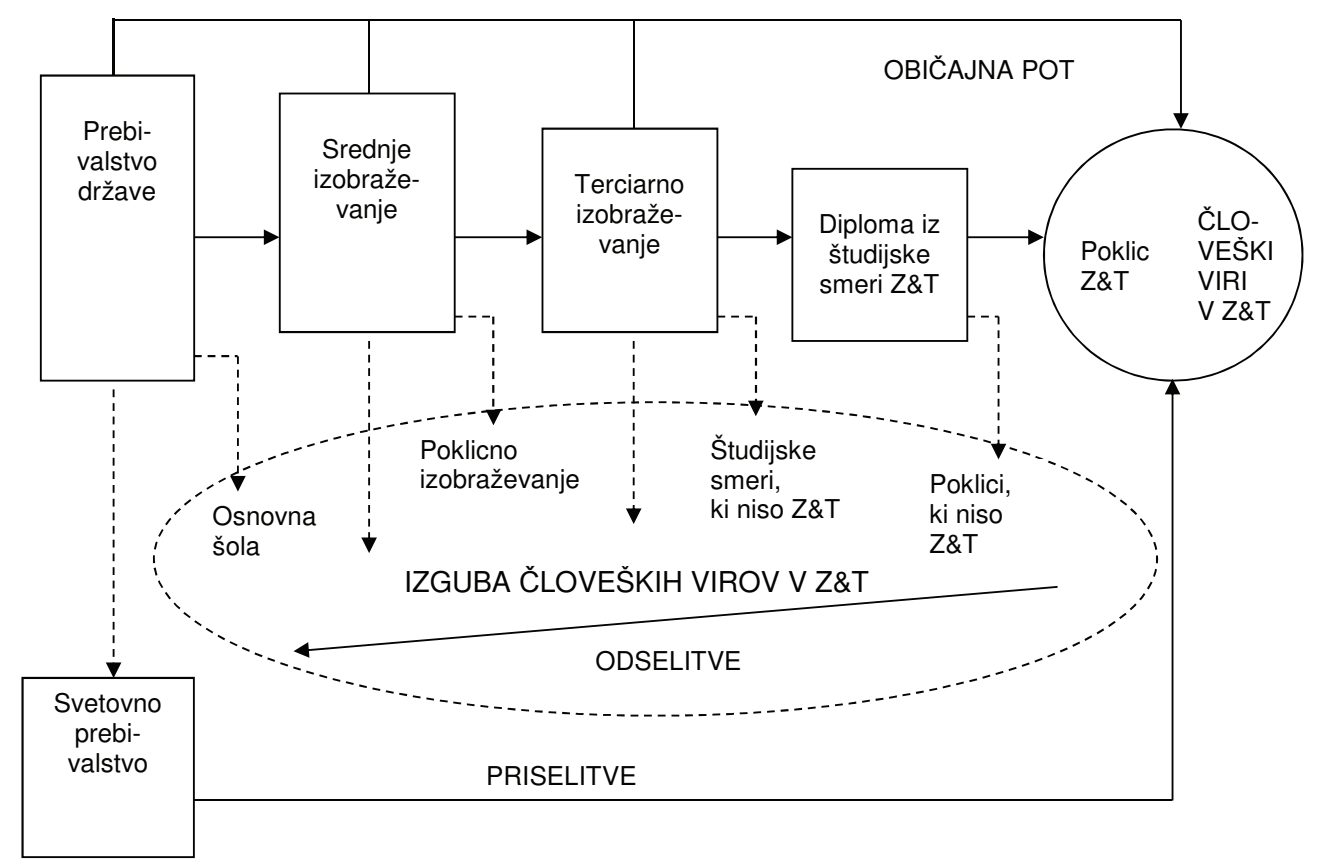

Slika 1. Izguba človeških virov v znanosti in tehnologiji (Bevc, 2007). Vir: European Commission (2003). Z\&T je kratica za "znanost in tehnologija". 
Merila in kriteriji za to štipendijo so bila naslednja:

- najmanj prav dober uspeh $\mathrm{v}$ sedmem in osmem razredu OŠ, oziroma najmanj dober uspeh v tretjem in četrtem razredu za kandidate iz srednjih šol;

- nadpovprečne umske zmožnosti in nadpovprečne specifične zmožnosti, ki so pomembne za izbran študij, kar se je ugotavljalo na osnovi testov sposobnosti (DAT serija - Differential Aptitude Test ali Test razlikovalnih sposobnosti);

- nizko socialnoekonomsko stanje družine, ki je onemogočalo vzdrževanje otroka $\mathrm{v}$ času šolanja (veliko število otrok, nizki dohodki).

Pri izenačenih pogojih so imeli prednost kandidati, ki so si izbrali smer šolanja, za katero na ožjem področju ni bilo zanimanja, in tisti iz gospodarsko manj razvitih občin.

Zanimivo je, da ima Nemčija še danes podoben sistem štipendiranja nadarjenih, saj štipendije za nadarjene podeljujejo samo tistim kandidatom, ki se želijo po predhodno zaključeni triletni poklicni oziroma vajeniški šoli vpisati na univerzo. Za štipendijo ne morejo sami kandidirati, ampak jih predlagajo predstojniki poklicne šole ali delodajalci (ŠOS, Predlog zakona o štipendiranju, 2012). Namen štipendiranja nadarjenih je torej podoben, in sicer omogočiti nadaljnje izobraževanje tistim sposobnim dijakom, ki se brez take pomoči za nadaljevanje študija ne bi odločili.

Po nekaj letih so sklad »Milijoni za talente« ukinili, ker je po mnenju tedanjih oblasti štipendiranje nadarjenih spodbujalo »elitizem«, ne glede na dejstvo, da so štipendijo prejemali samo najrevnejši med nadarjenimi. Leta 1974 so sprejeli nov družbeni dogovor o štipendiranju, ki je temeljil na kadrovskih štipendijah in na štipendijah iz združenih sredstev za revne dijake in študente, ki niso dobili kadrovske štipendije. Poleg obeh vrst štipendij so kasneje ustanovili še dva štipendijska sklada, in sicer Titov sklad za štipendiranje družbeno aktivnih in nadarjenih mladih delavcev in otrok delavcev, ki je bil po letu 1991 ukinjen, in Kraigherjev sklad za štipendiranje študentov za potrebe raziskovalne dejavnosti, ki se je po letu 1991 preimenoval v Mundov sklad (deloval je do leta 1999). Po podatkih iz ankete med diplomanti, ki je bila izvedena leta 1984, je kar $75 \%$ diplomantov v času študija prejemalo štipendijo (Stergar, 1988). Največ štipendistov je imelo kadrovsko štipendijo (57 \%), tretjina (31 \%) je prejemala štipendijo iz združenih sredstev, $4 \%$ so prejemali Titovo štipendijo in $1 \%$ Kraigherjevo štipendijo. Šest odstotkov jih je prejemalo tudi dodatek h kadrovski štipendiji iz združenih sredstev. Iz današnje perspektive se zdi, da je bila štipendijska politika bolje urejena kot danes, ko štipendijo prejema le okoli četrtina študentov (SURS, 2015), a je treba upoštevati, da sedaj študira bistveno več mladih kot nekoč. Glavna pomanjkljivost takratnega štipendiranja je bila $v$ tem, da je spodbujalo predvsem izobraževanje na nižjih zahtevnostnih stopnjah, za katero je bilo razpisanih bistveno več kadrovskih štipendij kot za visokošolsko izobraževanje na VI. In VII. stopnji zahtevnosti.

\section{Štipendiranje nadarjenih na Republiškem zavodu za zaposlovanje $\mathbf{v}$ osemdesetih letih}

Sredi osemdesetih let so bile družbene razmere ugodne za oživitev ideje o štipendiranju nadarjenih. Hitrejši gospodarski razvoj je zahteval visoko izobražene kadre, ki jih na trgu delovne sile ni bilo dovolj. Prevladovalo je prepričanje, da mora Slovenija več vlagati v izobraževanje in spodbuditi mlade za študij. Podatki iz vzdolžnega spremljanja generacije osmošolcev skozi srednješolsko in visokošolsko izobraževanje so pokazali, da kadrovske štipendije in štipendije iz združenih sredstev niso zadoščale, saj se še vedno pomemben delež (30 \%) izjemno sposobnih učencev ni vključil $\mathrm{v}$ visokošolsko izobraževanje (Makarovič, 1984). Glavni razlog za to "podrealizacijo« ali premalo izkoriščen talent je Makarovič pripisal faktorju okolja, katerega bistveni negativni vpliv so predstavljale slabe socialnoekonomske razmere (nižja izobrazba staršev) in z njimi povezano pomanjkanje spodbud. Zasluge za ponovno oživitev štipendiranja nadarjenih ima psiholog Janez Zalaznik, takratni vodja službe za poklicno usmerjanje na Republiškem zavodu za zaposlovanje (v nadaljevanju "Zavod"), ki je odgovorne prepričal, da ima Zavod dovolj kadrovskih virov za izvedbo projekta štipendiranja nadarjenih. Pobudo o štipendiranju nadarjenih so spomladi 1986 potrdili v vseh občinskih skupnostih za zaposlovanje in sprejeli spremembo družbenega dogovora o štipendiranju, s katero so dopolnili obstoječ štipendijski sistem z višjim materialnim cenzusom za nadarjene dijake in študente. Le-ta je bil precej višji od cenzusa za štipendije iz združenih sredstev, tako da le kandidati iz premožnih družin niso mogli dobiti štipendije, čeprav so lahko bili predlagani, in so lahko pridobili status Zoisovega štipendista brez štipendije (Zalaznik, 1989a). Postopek podelitve štipendije je potekal v dveh fazah. $V$ prvi fazi so šole predlagale ustrezne kandidate $\mathrm{v}$ skladu z razpisnimi pogoji, v drugi fazi pa so psihologi na Zavodu predlagane kandidate dodatno testirali in ovrednotili njihove dosežke na tekmovanjih. Mnenje psihologa o izpolnjevanju meril in kriterijev za dodelitev štipendije je morala potrditi še strokovna komisija, ki so jo sestavljali vsi psihologi v posamezni regiji. Če odločitev v regijski komisiji ni bila soglasna (ali v primeru pritožb zavrnjenih kandidatov), je končno odločitev sprejela strokovna komisija na centralni službi Zavoda.

V prvem obdobju od 1986 do 1991 so se štipendije za nadarjene podeljevale na osnovi naslednjih meril in kriterijev:

1. visok(i) rezultat(i) na vsaj enem testu intelektualnih sposobnosti (MFBT - Multifaktorska baterija testov, PM - Standardne progresivne matrice, DAT serija A Presojanje abstraktnih odnosov, DAT serija B - Presojanje besednih odnosov; uvrstitev v zgornjih 2,28 \% oziroma presežen 97. percentil);

2. visok(i) dosežek(ki) na tekmovanjih (zlato priznanje, prejem prve do tretje nagrade),

3. odličen učni uspeh (povprečna ocena višja od 8,5 pri študentih). 
Vsi dijaki so morali imeti najmanj prav dober učni uspeh (najmanj povprečna ocena 8,0 pri študentih). Štipendijo so dobili kandidati, ki so izpolnjevali vsaj dve od treh meril. Kandidati iz srednjih šol in visokošolskih zavodov so morali obvezno imeti tudi javno priznan izjemni dosežek. V praksi se je dogajalo, da šole niso hotele predlagati kandidatov, ki so sicer na testih izpolnjevali merila, a so bili po mnenju učiteljev premalo učno aktivni. Po drugi strani pa so raje predlagali odličnjake, kar so dojemali kot nagrado za njihovo prizadevnost pri pouku. Analiza izvajanja štipendiranja nadarjenih $\mathrm{v}$ prvih treh letih je osvetlila nekatere značilnosti štipendiranja, ki niso bile spodbudne (Zalaznik, 1989b). Mnogo nadarjenih iz socialnoekonomsko podpovprečnega okolja sploh ni bilo predlaganih, šole pa so raje predlagale učence $\mathrm{z}$ odličnim uspehom kot pa sposobne učence $\mathrm{s}$ prav dobrim uspehom. Ker je učni uspeh močno povezan $s$ socialnoekonomskim statusom (izobrazbo staršev), so bili v prednosti nadarjeni z odličnim uspehom in tisti, ki so imeli bolj izobražene starše (Zalaznik, 1989b). Zalaznik se je tudi zavzemal, da bi v Sloveniji izdelali celovit sistem dela $\mathrm{z}$ nadarjenimi, ki bi spodbudil zgodnejše odkrivanje in delo $\mathrm{z}$ nadarjenimi, razvoj dodatnih aktivnosti in programov dela z njimi, štipendiranje in zaposlovanje nadarjenih (Zalaznik, 1996). V okviru takega sistema bi bila podpora nadarjenim iz socialnoekonomsko manj ugodnega okolja bolj učinkovita. Obstajale so že konkretne zamisli o izgradnji takega sistema, vendar do njegove uresničitve takrat ni prišlo (Pivec, 1989).

Leta 1990 je Makarovič na podlagi večletne empirične raziskave razlik med nadarjenimi in ostalimi učenci predlagal spremembo instrumentarija in postopka za odkrivanje nadarjenih za potrebe štipendiranja, v katerem imajo večjo težo visoke sposobnosti in dosežki, učni uspeh pa predstavlja samo še vstopni pogoj, ki se ne točkuje (Makarovič, 1990). $\mathrm{Na}$ podlagi njegovega predloga so se leta 1991 spremenila merila in kriteriji za dodelitev Zoisove štipendije.

\section{Postopek izbora kandidatov in merila pri podeljevanju Zoisovih štipendij na Zavodu v devetdesetih letih}

Po osamosvojitvi Slovenije leta 1991 je prišlo do pomembnih sprememb. Normativno so štipendije za nadarjene bile urejene $\mathrm{z}$ zakonom $\mathrm{o}$ zaposlovanju in zavarovanju za primer brezposelnosti (ZZZPB), ki je bila sprejet leta 1991. Štipendije za nadarjene so se preimenovale v Zoisove štipendije, s čimer se je želelo poudariti njihovo vlogo pri podpiranju izobraževanja bodočih perspektivnih strokovnjakov, ki jih nova država potrebuje. Merila pri podeljevanju Zoisovih štipendij so se spremenila. Učni uspeh ni bil več del meril, ampak je predstavljal samo vstopni pogoj (najmanj prav dober uspeh oziroma najmanj povprečna ocena 8,0 pri študentih). Najpomembnejše merilo so postale visoke sposobnosti v kombinaciji z dosežki na tekmovanjih. Bistvena sprememba je bila ta, da so po novem lahko Zoisovo štipendijo dobili tudi potencialno nadarjeni z najmanj prav dobrim učnim uspehom, ki so se po svojih sposobnostih uvrščali med zgornjih 2,28 \% in (še) niso imeli dosežkov na tekmovanjih. Če jih šola ni hotela predlagati, je take kandidate v skladu z novim pravilnikom o štipendiranju (Pravilnik o spremembah in dopolnitvah pravilnika o štipendiranju, 1997, 12. člen) lahko predlagal psiholog na Zavodu.

Nova merila so bila kvantificirana in normirana, kar je omogočilo seštevanje točk na posameznih merilih oziroma izračun skupnega dosežka.

Za dodelitev Zoisove štipendije so morali biti izpolnjeni naslednji pogoji:

- pogoj intelektualne ali umetniške nadarjenosti,

- pogoj učnega uspeha (prav dober za učence in dijake ter 8,0 za študente) in

- pogoj materialnega cenzusa (do leta 1996),

- javno priznan uspeh ali izjemni dosežek (dodatni pogoj, ki je veljal samo za kandidate iz srednjih šol in fakultet).

Kandidat je izpolnil pogoj intelektualne nadarjenosti, če je na osnovnih in dodatnih merilih zbral najmanj 20 normiranih točk. Osnovno merilo je predstavljalo oceno stopnje intelektualnih sposobnosti kandidata in se je glede na izpolnjen kriterij delilo na prvo, drugo in tretje osnovno merilo (tretje osnovno merilo je bilo dodano leta 1996).

Prvo osnovno merilo (indeks INT $=20$ ) je bilo vredno 20 normiranih točk, ki jih je dobil kandidat, ki je na multifaktorskem testu (MFBT, Wechsler-Bellevue [WB-II], Bujasova MR-serija) dosegel skupni rezultat, ki je ustrezal 97. percentilu ali več. Drugo osnovno merilo (indeks INT $=10$ ) je bilo vredno 10 normiranih točk, ki jih je dobil kandidat, ki je na posameznem intelektualnem podtestu multifaktorskega testa (MFBT 3 - Tridimenzionalni prostor, MFBT 4 Besednjak, MFBT 6 - Numerični problemi) dosegel rezultat 97. percentil ali več, pri čemer je moral skupni rezultat na vseh intelektualnih podtestih ustrezati vsaj 90. do 97. percentilu, in tisti, ki je na enofaktorskem testu intelektualnih sposobnosti (DAT-A, DAT-B, APM-II, Domino D-48) dosegel rezultat 97. percentil ali več. Tretje osnovno merilo (indeks INT $=5$ ) je bilo vredno 5 normiranih točk, ki jih je dobil kandidat, ki je na multifaktorskem testu dosegel skupni rezultat vsaj 90. percentil (in nižji od 97. percentila). Mejne vrednosti so bile točno določene. $\mathrm{V}$ primeru rezultata tik pod zahtevano mejo se je izvedlo še dodatno testiranje z drugim testom.

Dodatna merila so bila tri: merilo tekmovalnih dosežkov (indeks TEKM), merilo intelektualne usmerjenosti učenca (indeks UC) in merilo socialne prikrajšanosti učenca (indeks SOC). Indeks TEKM je predstavljala vsota ocenjenih posameznikovih dosežkov na tekmovanjih iz znanja na regijskih in državnih tekmovanjih. Ti so se ovrednotili na osnovi vnaprej določenega seznama tekmovanj in možnih posameznih dosežkov (srebrno priznanje je prineslo 4 surove točke, zlato priznanje 8 surovih točk in prva do tretja nagrada 16 surovih točk). Na indeksu TEKM je lahko kandidat dobil 5 normiranih točk (za vsoto surovih točk med 8 in 15) ali 10 normiranih točk (za vsoto najmanj 16 surovih točk). Istovrstna tekmovanja so se vrednotila samo enkrat, upošteval se je najvišje ocenjen dosežek.

Točke na indeksu UC so se določale na podlagi ovrednotenih odgovorov na Vprašalniku o poklicni poti (VPP), ki so po vsebini predstavljali lastno oceno učenca o svojih sposobnostih, o želji po dolgotrajnejšem izobraževanju ter motiviranosti za poglobljen študij in raziskovalno delo. Vrednotenje odgovorov na VPP je bilo računalniško vodeno. 
Kandidat je na indeksu UC lahko dobil 5 normiranih točk, če je vsota surovih točk bila najmanj 12 .

Točke na merilu SOC so se določale na osnovi podatkov o socialnoekonomskem stanju in izobrazbeni strukturi družine, ki so jih zapisali vlagatelji na drugo stran predloga za Zoisovo štipendijo. Na podlagi višine prejetega otroškega dodatka se je določil dohodkovni razred družine. Vrednotenje odgovorov je bilo računalniško vodeno. Kandidat je na indeksu SOC lahko dobil 5 normiranih točk, če je vsota surovih točk znašala najmanj 10.

Kandidat, ki na osnovnem merilu ni dosegel nobene točke, ni mogel dobiti štipendije ne glede na število zbranih točk na dodatnih merilih. Merila za izbor Zoisovih štipendistov so torej vključevala vse bistvene komponente nadarjenosti: visoke sposobnosti kot dispozicije (indeks INT), izražene sposobnosti v obliki dosežkov (indeks TEKM) in notranjo motivacijo za študij in dodatne aktivnosti na področju razvoja talenta (indeks UC). Indeks SOC je omogočal kandidatom, ki so živeli v slabših socialnoekonomskih razmerah, da so pridobili dodatne točke, $\mathrm{s}$ katerimi so lahko v kombinaciji s točkami na indeksu TEKM in indeksu INT izpolnili pogoje za dodelitev Zoisove štipendije, tudi če na indeksu UC niso dobili nobene točke. Indeksa SOC in UC sta se izračunavala samo za kandidate iz osnovnih šol, kajti za kandidate iz srednjih šol in univerz je bil javno priznan izjemni dosežek obvezen, zato so lahko že na dodatnem merilu TEKM v kombinaciji s prvim ali drugim osnovnim merilom zbrali dovolj za dodelitev štipendije.

Kandidati za štipendijo za umetniško nadarjenost so se edini izognili postopku ugotavljanja intelektualne nadarjenosti. Za izpolnjen pogoj umetniške nadarjenosti na določenem umetnostnem področju se je štelo: prejem državnega priznanja ali nagrade, uvrstitev do vključno 3. mesta na državnem tekmovanju, mednarodno priznanje ali nagrada oziroma uvrstitev $\mathrm{v}$ finale mednarodnih tekmovanj (po predhodnem izboru na državnem tekmovanju). V primeru nastopov v duetu ali triu, se je upošteval le prejem prve nagrade na državnem tekmovanju ali uvrstitev do vključno 3. mesta na mednarodnem tekmovanju. Zavod pa je lahko upošteval tudi mnenje vsaj dveh neodvisnih strokovnjakov z ustreznega umetnostnega področja.

Za javno priznan uspeh oziroma izjemni dosežek je za dijake veljalo: zlato priznanje ali prvo do tretje mesto na državnem tekmovanju, udeležba na mednarodnem tekmovanju po predhodnem izboru na državnem tekmovanju, nagrajeno umetniško ali raziskovalno delo na državni ravni, v strokovni reviji objavljena pozitivna recenzija o kandidatovih umetniških ali raziskovalnih prispevkih ter najmanj 30 točk na maturi.

Pri študentih so za javno priznan uspeh ali izjemni dosežek veljali: nagrajeno umetniško ali znanstveno-raziskovalno delo ali nagrajena diplomska naloga $\mathrm{v}$ državni konkurenci, objava individualne raziskovalne naloge $\mathrm{v}$ priznani strokovni reviji ali strokovnem zborniku in priložena pozitivna recenzija naloge in $\mathrm{v}$ strokovni reviji objavljena pozitivna recenzija o kandidatovih umetniških ali znanstveno-raziskovalnih prispevkih.

Pogoj za ohranitev Zoisove štipendije je bil sprva postavljen nizko, in sicer najmanj dober uspeh (dijaki) in najmanj povprečna ocena 7,0 (študenti) v preteklem šolskem ali študijskem letu. Namen tega blagega kriterija je bil, da bi lahko štipendijo ohranilo čimveč nadarjenih iz nižjega socialnoekonomskega okolja, ki so v povprečju dosegali nižji učni uspeh kot nadarjeni iz bolje situiranih družin. V praksi se je pokazalo, da je bil kriterij za ohranitev štipendije prenizek in Zoisovih štipendistov ni dovolj motiviral $\mathrm{k}$ doseganju višjih ocen. Zato je Zavod leta 1997 predlagal spremembo pravilnika o štipendiranju (Pravilnik o spremembah in dopolnitvah pravilnika o štipendiranju, 1997, 20. člen), s katero so se pogoji za ohranitev Zoisove štipendije zaostrili. Pri dijakih se je zahteval najmanj prav dober uspeh, pri študentih pa najmanj povprečna ocena 8,0 . Zaostritev pogojev je pripomogla $\mathrm{k}$ višji učni uspešnosti Zoisovih štipendistov (Gabršček, 2004). Na pobudo Ministrstva za družino, delo in socialne zadeve (MDDSZ) so se leta 1999 pogoji za ohranitev Zoisove štipendije spet omilili in se vrnili na tiste, ki so veljali pred letom 1997 (Pravilnik o štipendiranju, 1999). To je bila ena od napačnih odločitev, ki je kasneje spodbudila kritiko zavrnjenih kandidatov na račun prejemnikov Zoisove štipendije s povprečnim učnim uspehom.

Leta 1996 se je zgodila nova bistvena sprememba, ko je prišlo do ukinitve materialnega cenzusa, s čimer se je spremenil namen Zoisovega štipendiranja. Štipendije niso bil več namenjene samo nadarjenim z nizkim do povprečnim socialnoekonomskim statusom (SES), ki so štipendijo potrebovali predvsem za kritje stroškov študija, ampak vsem nadarjenim kot spodbuda za razvoj njihovih potencialov. Zoisova štipendija je $v$ javnosti in med mladimi pridobila na veljavi in je tistim, ki niso imeli materialnih ovir za študij, pomenila predvsem priznanje za dosedanjo uspešnost, pa tudi statusni simbol oziroma nekakšno dokazilo o nadarjenosti. Postavilo pa se je vprašanje, kakšno funkcijo ima Zoisova štipendija, če ni več vezana na materialni položaj posameznika. V ožjem ekonomističnem pogledu je namreč naložba države koristnejša, če se podpre nadarjene, ki živijo v slabših socialnoekonomskih razmerah, ker gre v tem primeru za preprečevanje izgube človeških virov, medtem ko pri dobro preskrbljenih nadarjenih do izgube ne pride, saj bi doštudirali tudi brez štipendije. Na Zavodu za zaposlovanje so poudarjali, da ima Zoisovo štipendiranje naslednje cilje: a) povečati delež realiziranih nadarjenih $\mathrm{z}$ visoko izobrazbo ne glede na njihov socialni izvor; b) povečati študijsko uspešnost izrazito nadarjenih dijakov in študentov ter skrajšati čas študija; c) spodbuditi povezovanje med Zoisovimi štipendisti in delodajalci že v času študija ter povečati njihove možnosti zaposlovanja v Sloveniji, in tako preprečiti "beg možgan" v tujino; d) zagotoviti dovolj perspektivnih kadrov za potrebe hitrejšega gospodarskega, družbenega in kulturnega razvoja Slovenije (Nagy, 2005).

Ukinitev materialnega cenzusa in omilitev kriterija učnega uspeha za ohranitev Zoisove štipendije sta sprožila povečano zanimanje mladih za Zoisovo štipendijo (predvsem odličnjakov iz osnovnih šol). Šole so pod pritiskom staršev predlagale tudi odlične učence, ki na testih sposobnosti niso dosegali zahtevanih kriterijev (tudi po dodatnem testiranju), zato se je število zavrnjenih kandidatov povečalo, kar je povzročalo občutke nezadovoljstva in razočaranja, pa tudi dvomov o ustreznosti meril za dodelitev Zoisove štipendije. Jezo je povzročalo tudi dejstvo, da so nekateri Zoisovi štipendisti, ki so izpolnili merila intelektualne nadarjenosti, 
Tabela 1. Osnovna in dodatna merila - struktura odobrenih kandidatov iz OŠ v šolskem letu 2005/06

\begin{tabular}{|c|c|c|c|c|c|c|c|c|}
\hline Dodatna merila & $\mathrm{INT}=20$ & Delež & $\mathrm{INT}=10$ & Delež & $\mathrm{INT}=5$ & Delež & Skupaj & $\begin{array}{r}\text { Delež } \\
8\end{array}$ \\
\hline & & 2 & 3 & 4 & 5 & 0 & 1 & \\
\hline $\mathrm{TEKM}=0$ & 348 & $41 \%$ & 0 & - & 0 & - & 348 & $25 \%$ \\
\hline $\mathrm{TEKM}=5$ & 257 & $30 \%$ & 260 & $63 \%$ & 0 & - & 517 & $38 \%$ \\
\hline $\mathrm{TEKM}=10$ & 251 & $29 \%$ & 154 & $37 \%$ & 93 & $100 \%$ & 498 & $37 \%$ \\
\hline $\mathrm{UC}=5$ & 521 & $61 \%$ & 346 & $84 \%$ & 92 & $99 \%$ & 959 & $70 \%$ \\
\hline $\mathrm{SOC}=5$ & 153 & $18 \%$ & 86 & $21 \%$ & 14 & $15 \%$ & 253 & $18 \%$ \\
\hline Vsi odobreni & 856 & & 414 & & 93 & & 1363 & $100 \%$ \\
\hline Delež & $63 \%$ & & $30 \%$ & & $7 \%$ & & & \\
\hline
\end{tabular}

Opombe: V stolpcih 1 in 2 so podatki o Zoisovih štipendistih z izpolnjenim prvim osnovnim merilom (INT $=20$ - po svojih splošnih intelektualnih sposobnostih se uvrščajo med zgornjih $3 \%$ ), v stolpcih 3 in 4 so podatki o Zoisovih štipendistih z izpolnjenim drugim osnovnim merilom (INT $=10$ - po svojih specifičnih sposobnostih se uvrščajo med zgornjih $3 \%$ in po svojih splošnih intelektualnih sposobnostih med zgornjih $10 \%$ ), $\mathrm{v}$ stolpcih 5 in 6 so podatki o Zoisovih štipendistih z izpolnjenim tretjim osnovnim merilom (INT $=5$ - po svojih splošnih intelektualnih spodobnostih se uvrščajo med zgornjih $10 \%$ ), v stolpcih 7 in 8 so združeni podatki in predstavljena struktura vseh Zoisovih štipendistov v 1.letniku srednje šole $\mathrm{v}$ šolskem letu 2005/06. TEKM $=0$ (na indeksu tekmovalnih dosežkov niso dobili nobene normirane točke oziroma niso imeli dosežkov), TEKM = 5 (na indeksu tekmovalnih dosežkov so dobili 5 normiranih točk - osvojili so najmanj 2 srebrni priznanji ali 1 zlato priznanje na državnem tekmovanju, TEKM $=10$ (na indeksu tekmovalnih dosežkov so dobili 10 normiranih točk - osvojili so najmanj 4 srebrna priznanja ali 2 zlati priznanji ali prvo do tretjo nagrado na državnem tekmovanju). UC $=5$ (na indeksu intelektualne usmerjenosti učenca so dobili 5 normiranih točk - so vedoželjni in visoko motivirani za dolgotrajno izobraževanje). SOC = 5 (na indeksu socialne prikrajšanosti so dobili 5 normiranih točk - izhajajo iz družin z nizkim dohodkom na družinskega člana, starši nimajo višje ali visoke izobrazbe).

kasneje v srednji šoli imeli slabši učni uspeh od zavrnjenih kandidatov in niso izgubili štipendije. Pojavile so se težave v pojasnjevanju namena štipendiranja (Gabršček, 2004). Ali ni Zoisova štipendija namenjena tistim, ki si jo zaslužijo glede na svoje dosežke in učne uspehe? Zavrnjeni odličnjaki so v visokem učnem uspehu videli potrditev svoje nadarjenosti, ki pa ni bila potrjena $\mathrm{z}$ rezultatom na testu, zato so zahtevali spremembe, tako da bi učni uspeh dobil večjo veljavo pri izboru Zoisovih štipendistov. MDDSZ je popustilo pritiskom javnosti in se po letu 2005 odločilo, da je potrebno merila za Zoisove štipendije spremeniti in jih zaostriti. Leta 2007 je bil sprejet zakon o štipendiranju (ZŠtip), ki je postavil nova merila, ki so popolnoma spremenila prvotni namen Zoisovih štipendij v nagrajevanje najuspešnejših, o čemer več kasneje.

\section{Ustreznost meril za izbor Zoisovih štipendistov na Zavodu v obdobju od 1996 do 2007}

Od leta 1996 dalje se je vsako leto po končanem izboru analiziralo strukturo novih Zoisovih štipendistov po posameznih merilih, kot tudi strukturo zavrnjenih kandidatov (Nagy, 2006). Analiza naj bi pokazala, kako dober je bil izbor, oziroma kakšne so razlike med izbranimi in zavrnjenimi kandidati. Ker se merila med posameznimi leti niso spreminjala, lahko kot primer služi analiza za šolsko leto 2005/06. Med 2609 predlaganimi kandidati iz osnovnih šol je merila izpolnilo 1363 kandidatov, 1246 pa je bilo zavrnjenih. Primerjava struktur obeh skupin je pokazala, da so dejansko bile med njimi pomembne razlike $\mathrm{v}$ sposobnostih in dosežkih na tekmovanjih, medtem ko so bile razlike $\mathrm{v}$ motivaciji manjše. V skupini odobrenih Zoisovih štipendistov so vsi izpolnili eno od osnovnih meril (med njimi $63 \%$ prvo osnovno merilo, $30 \%$ drugo osnovno merilo in $7 \%$ tretje osnovno merilo), $75 \%$ je imelo tekmovalne dosežke (od tega jih je bila polovica ali $38 \%$ z najvišjimi dosežki), $70 \%$ pa jih je bilo zelo motiviranih za dolgotrajni študij. Četrtina odobrenih kandidatov, ki ni imela točk na merilu TEKM, predstavlja t. i. potencialno nadarjene, ki so izpolnili prvo osnovno merilo (tabela 1).

Med zavrnjenimi kandidati je eno od osnovnih meril izpolnila le dobra polovica ( $20 \%$ je izpolnilo drugo osnovno merilo in $35 \%$ tretje osnovno merilo; tabela 2). Zavrnjeni so bili zato, ker na dodatnih merilih (predvsem na merilu TEKM) niso dosegli dovolj točk, da bi skupaj z osnovnim merilom zbrali najmanj 20 normiranih točk. Druga polovica zavrnjenih kandidatov (45\%) pa na testu(ih) sposobnosti ni dosegla kriterija, s katerim bi izpolnili katerega od osnovnih meril. Med vsemi zavrnjenimi kandidati jih je le ena četrtina imela dosežke na tekmovanjih (od tega le $2 \%$ najvišje dosežke), samo polovica pa je bila visoko motivirana za dolgotrajnejši študij $(\mathrm{UC}=5)$.

Navedeno kaže na pomanjkljivosti v postopku predlaganja kandidatov. Predlagatelji so slabo razlikovali med nadarjenimi in učno uspešnimi učenci, ali pa so enostavno popustili pritiskom staršev in dokočno izbiro prepustili odgovornim na Zavodu. Omeniti velja, da so imeli nadarjeni iz socialnoekonomsko šibkega okolja $(\mathrm{SOC}=5)$ skoraj enake možnosti, da izpolnijo merila za dodelitev Zoisove štipendije kot njihovi sovrstniki iz bolje situiranih družin (med odobrenimi Zoisovimi štipendisti jih je bilo $18 \%$, med zavrnjenimi kandidati pa $25 \%$ ).

Podrobnejša analiza najsposobnejših z izpolnjenim prvim osnovnim merilom je pokazala, da je med njimi le $60 \%$ imelo dosežke na tekmovanjih (TEKM 5 ali TEKM 10) in prav tako le $60 \%$ ustrezno motivacijo za dolgotrajnejši študij $(\mathrm{UC}=5$; tabela 1). Vsekakor ti podatki kažejo, da se je $\mathrm{v}$ osnovnih šolah premalo sistematično delalo z najsposobnejši učenci, kajti določen delež nadarjenih ni razvil ustrezne 
Tabela 2. Osnovna in dodatna merila - struktura zavrnjenih kandidatov

\begin{tabular}{|c|c|c|c|c|c|c|c|c|}
\hline Dodatna merila & $\mathrm{INT}=10$ & Delež & $\mathrm{INT}=5$ & Delež & $\mathrm{INT}=0$ & Delež & Skupaj & Delež \\
\hline & 1 & 2 & 3 & 4 & 5 & 6 & 7 & 8 \\
\hline $\mathrm{TEKM}=0$ & 235 & $95 \%$ & 344 & $79 \%$ & 351 & $62 \%$ & 930 & $75 \%$ \\
\hline $\mathrm{TEKM}=5$ & 13 & $5 \%$ & 86 & $20 \%$ & 191 & $34 \%$ & 290 & $23 \%$ \\
\hline $\mathrm{TEKM}=10$ & 0 & - & 3 & $1 \%$ & 23 & $4 \%$ & 26 & $2 \%$ \\
\hline $\mathrm{UC}=5$ & 117 & $47 \%$ & 222 & $51 \%$ & 303 & $54 \%$ & 642 & $52 \%$ \\
\hline $\mathrm{SOC}=5$ & 55 & $22 \%$ & 114 & $26 \%$ & 140 & $25 \%$ & 309 & $25 \%$ \\
\hline Vsi zavrnjeni & 248 & $100 \%$ & 433 & $100 \%$ & 565 & $100 \%$ & 1246 & $100 \%$ \\
\hline Delež & $20 \%$ & & $35 \%$ & & $45 \%$ & & & \\
\hline
\end{tabular}

Opombe: V stolpcih 1 in 2 so podatki o zavrnjenih kandidatih z izpolnjenim drugim osnovnim merilom (INT = 10 - po svojih specifičnih sposobnostih se uvrščajo med zgornjih $3 \%$ in po svojih splošnih intelektualnih sposobnostih med zgornjih $10 \%$ ), ki na dodatnih merilih TEKM, UC in SOC niso skupaj zbrali 10 točk, v stolpcih 3 in 4 so podatki o zavrnjenih kandidatih z izpolnjenim tretjim osnovnim merilom (INT $=5-$ po svojih splošnih intelektualnih spodobnostih se uvrščajo med zgornjih $10 \%$ ), ki na dodatnih merilih TEKM, UC in SOC niso skupaj zbrali 15 točk, v stolpcih 5 in 6 je struktura zavrnjenihkandidatov, ki niso izpolnili osnovnega merila (INT = 0 ), v stolpcih 7 in 8 so združeni podatki in predstavljena struktura vseh zavrnjenih kandidatov iz OŠ v šolskem letu 2005/06. TEKM = 0 (na indeksu tekmovalnih dosežkov niso dobili nobene normirane točke oziroma niso imeli dosežkov), TEKM $=5$ (na indeksu tekmovalnih dosežkov so dobili 5 normiranih točk - osvojili so najmanj 2 srebrni priznanji ali 1 zlato priznanje na državnem tekmovanju, TEKM = 10 (na indeksu tekmovalnih dosežkov so dobili 10 normiranih točk - osvojili so najmanj 4 srebrna priznanja ali 2 zlati priznanji ali prvo do tretjo nagrado na državnem tekmovanju). UC $=5$ (na indeksu intelektualne usmerjenosti učenca so dobili 5 normiranih točk - so vedoželjni in visoko motivirani za dolgotrajno izobraževanje). $\mathrm{SOC}=5$ (na indeksu socialne prikrajšanosti so dobili 5 normiranih točk - izhajajo iz družin z nizkim dohodkom na družinskega člana, starši nimajo višje ali visoke izobrazbe).

notranje motivacije za osebno izpopolnjevanje. Psihologi na Zavodu so bili prepričani, da bo podelitev Zoisove štipendije potencialno nadarjenim učencem dala pomembno spodbudo za bolj poglobljeno učenje in dodatne aktivnosti, ki vodijo v smer razvoja njihovih potencialov skozi srednješolsko in visokošolsko izobraževalno potjo (slika 2).

Merila za dodelitev Zoisove štipendije niso bila občutljiva na razlike $\mathrm{v}$ razvitosti regije, saj je bil delež Zoisovih štipendistov-študentov med vsemi prebivalci v manj razvitih regijah celo nekoliko večji kot $\mathrm{v}$ bolj razvitih regijah (Nagy, 2005). Po ukinitvi materialnega cenzusa pa je prišlo do spremembe $\mathrm{v}$ strukturi Zoisovih štipendistov, tako da se je delež Zoisovih štipendistov-dijakov v bolj razvitih regijah začel povečevati, v manj razvitih pa zniževati. Razvitost regije pa je očitno vplivala na uspešnost Zoisovih štipendistov, saj so Zoisovi štipendisti-študenti iz bolj razvitih regij bili pri študiju uspešnejši od njihovih vrstnikov iz manj razvitih regij, kar pomeni, da slednji svojih slabših začetnih položajev v času izobraževanja niso uspeli v celoti nadoknaditi.

\section{Kritika Zoisovih štipendij na Zavodu po letu 1996}

Po letu 1996, ko je bil odpravljen materialni cenzus, se je $\mathrm{z}$ večanjem števila zavrnjenih kandidatov povečalo število pritožb, a njihovo število nikoli ni preseglo $10 \%$ zavrnjenih kandidatov. Večina pripomb se je nanašala na merila in kriterije za dodelitev Zoisove štipendije (predvsem na srednješolski in visokošolski stopnji), nekateri pa se niso strinjali s preblagimi kriteriji za ohranitev štipendije. Na Zavodu za zaposlovanje so se zato odločili za evalvacijsko študijo Zoisovih štipendij, da bi z njo prepoznali morebitne pomanjkljivosti ali šibkosti Zoisovega štipendiranja in jih v naslednjih letih odpravili. V

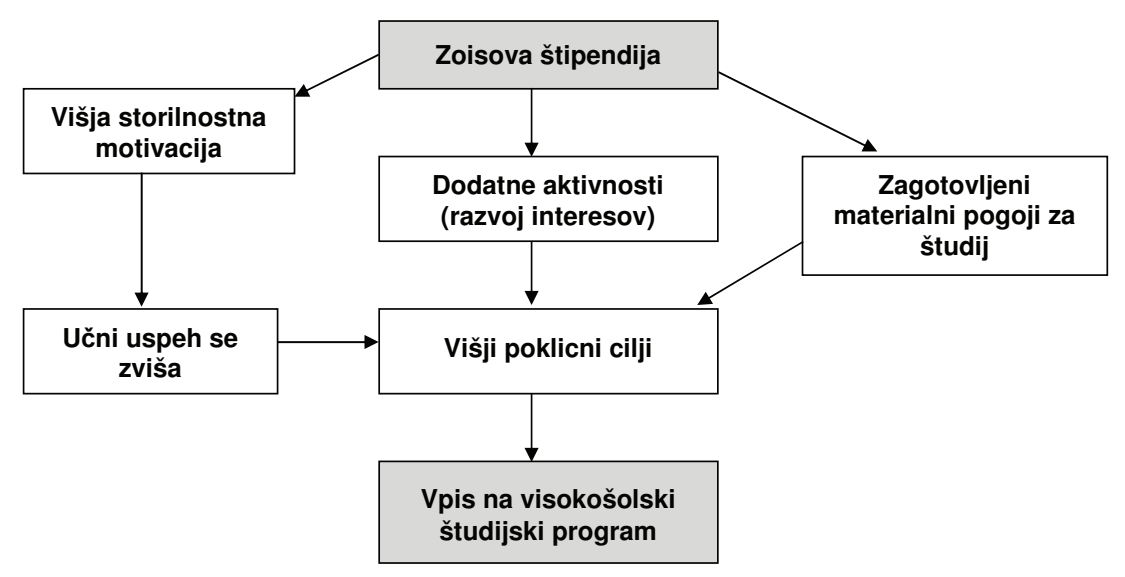

Slika 2: Vpliv Zoisove štipendije na višjo realizacijo nadarjenih (Nagy, 2005). 
evalvacijski študiji Zoisovih štipendij je bilo ugotovljeno, da namen Zoisovih štipendij ni dovolj natančno definiran, zlasti po ukinitvi cenzusa (Gabršček, 2004). Študija je opozorila na prehitro spreminjanje meril in kriterijev brez predhodne simulacije, ki bi pokazala, do česa lahko sprememba pripelje. Ta opozorila kasneje niso bila upoštevana. Med predlogi za izboljšave se je predlagalo uvedbo različnih višin Zoisove štipendije glede na materialno stanje družine ali pa kombinacijo državne in Zoisove štipendije ter spremljanje regijske pokritosti štipendistov, ki na nekaterih področjih, ki so deprivilegirana, ni bila ustrezna. Potrebno bi bilo določiti, katera inštitucija je odgovorna za določanje kriterijev za štipendije. Je to resorno ministrstvo s spremembo pravilnika ali so to strokovne službe Zavoda za zaposlovanje, ki lahko ocenijo potrebne spremembe? Postopke predlaganja kandidatov za Zoisove štipendije bi bilo potrebno preveriti, če res potekajo tako, kot je bilo predpisano. Pojavljali so se tudi očitki, da so nekateri kandidati iz posameznih okolij ali regij privilegirani v primerjavi z drugimi, predvsem s tistimi iz socialno šibkih okolij. Po uveljavitvi koncepta odkrivanja in dela z nadarjenimi učenci v osnovni šoli se lahko pričakuje bistveno povečanje števila identificiranih nadarjenih, kar lahko povzroči težave še zlasti takrat, ko bodo nekateri otroci $\mathrm{v}$ devetletni osnovni šoli prepoznani kot nadarjeni, ne bodo pa ustrezali kriterijem za Zoisovo štipendijo. Kot problematični so bili ocenjeni tudi kriteriji za ohranitev štipendije, ki so bili določeni za vse študijske programe enako, zato so se mnogi študenti upravičeno pritoževali, da so $\mathrm{v}$ neenakopravnem položaju v primerjavi s kolegi, ki hodijo na fakultete, kjer je povprečna ocena visoka. Študija je predlagala uvedbo faktorja (povprečna ocena fakultete), s katero bi ponderirali povprečno oceno štipendista in s tem zagotovili ustreznejše vrednotenje študijskega uspeha. Kot pomankljivost sistema Zoisovega štipendiranja se je ocenjevalo tudi dejstvo, da ne omogoča vzdolžnega spremljanja in analiz, ki bi lahko dajale povratne informacije o uspešnosti sistema štipendiranja.

Druga kritika je bila zapisana v Resoluciji o Nacionalnem programu visokega šolstva Republike Slovenije 2007-2010, ki so jo napisali na Ministrstvu za visoko šolstvo, znanost in tehnologijo (RNPVŠ 2007-2010; 2007). Po njihovem mnenju bi Zoisove štipendije morale biti namenjene najboljšim dijakom in študentom, hkrati pa bi morale $\mathrm{v}$ večji meri upoštevati pogoj učne uspešnosti (»odličnost uspeha«), ki je bil do takrat premalo poudarjen. Poročali so, da je slabost dosedanjih Zoisovih štipendij predvsem v tem, da dopuščajo enostaven dostop v začetni fazi, tj. ob koncu osnovne šole, a hkrati praktično ne omogočajo pridobitve te štipendije $v$ kasnejših letih na srednjih šolah in še zlasti ne v terciarnem izobraževanju, kjer bi bile bistevno bolj potrebne in v večji meri tudi usmerjevalne. Prav tako so se zavzemali za zvišanje kriterija za ohranitev Zoisove štipendije, s čimer bi zmanjšali število tedanjih Zoisovih štipendistov in sredstva namenili za podelitev štipendije uspešnejšim študentom. Štipendiranje nadarjenih študentov, ki dosegajo samo dober učni uspeh, ne dosegaciljarazvojatalentovvzadostnimeri.Zoisovištipendisti naj bi bili le redko deležni dodatnih izobraževalnih aktivnosti in so povečini ostajali $\mathrm{v}$ standardnem izobraževalnem okolju, ne da bi lahko svoje posebne sposobnosti dodatno razvijali. »Zato bi morali Zoisove štipendije usmerjati $\mathrm{v}$ nadstandardno izobraževanje, kot je vključevanje $\mathrm{v}$ raziskovalne projekte, plačevanje tutorstva, pripravljanje člankov, udeležba na znanstvenih in strokovnih sestankih, vključevanje v bodoča delovna okolja itd.« (RNPVŠ 20072010, 2007, str. 25). Nekatere kritične pripombe so vsekakor na mestu. Evalvacijska študija je pokazala, da se je zaradi omilitve kriterijev za ohranitev Zoisove štipendije po letu 1999 učna uspešnost Zoisovih štipendistov znižala, ker so se prilagodili nižjim kriterijem (Gabršček, 2004). Prav tako drži kritika, da bi kriteriji za ohranitev Zoisove štipendije morali biti prilagojeni zahtevnosti študijskih programov. Ni pa mogoče pritrditi mnenju, da bi Zoisove štipendije morale spodbujati »odličnost uspeha«, kajti v tem primeru bi se vloga Zoisovih štipendij zreducirala zgolj na nagrajevanje izrazito uspešnih, s čimer bi se materialna podpora preusmerila od nadarjenih $\mathrm{z}$ nizkim SES v manj razvitih regijah $\mathrm{k}$ uspešnim z višjim SES v bolj razvitih regijah, kar so potrdile tudi raziskave v ZDA (Heller in Marin, 2002). Prav tako ne drži očitek, da kandidati iz srednjih šol in fakultet skoraj niso mogli pridobiti Zoisove štipendije, saj jo je pridobilo okoli $25 \%$ predlaganih kandidatov iz srednjih šol in okoli $20 \%$ predlaganih kandidatov iz visokih šol in fakultet. Res pa je, da je bilo število predlaganih kandidatov na srednjih šolah in fakultetah sorazmerno majhno $\mathrm{v}$ primerjavi s številom kandidatov iz osnovnih šol, ker se je od njih zahtevalo izpolnjevanje dodatnega pogoja javno priznanega uspeha ali izjemnega dosežka kot dokaz že realizirane nadarjenosti.

\section{Zoisovo štipendiranje po letu 2007}

S šolskim letom 2008/09 je skladno z zakonom o štipendiranju (ZŠtip) naloge Zoisovega štipendiranja prevzel Javni sklad RS za razvoj kadrov in štipendije (v nadaljevanju "sklad") v Ljubljani, ki se je za to delo okrepil s kadri iz Zavoda RS za zaposlovanje (ZRSZ). Zakon je določil nov postopek podeljevanja štipendij, opredelil nova merila za dodelitev in zaostril pogoje za ohranitev Zoisove štipendije.

Postopek se je centraliziral, vse vloge se od leta 2008 obravnavajo na sedežu sklada. Kandidati za Zoisovo štipendijo se po novem lahko sami prijavijo za Zoisovo štipendijo. Izpolnjevanje meril se ugotavlja samo na podlagi dokumentacije, ki jo kandidati priložijo k vlogi, zato ni več dodatnega testiranja kandidatov. Od kandidatov iz osnovnih šol se je sprva zahtevalo tudi potrdilo o identificirani nadarjenosti $\mathrm{V}$ skladu $\mathrm{s}$ konceptom odkrivanja in dela $\mathrm{z}$ nadarjenimi učenci $\mathrm{v}$ osnovni šoli, po letu 2014 pa tega pogoja ni več. Novost predstavlja kvotni sistem podeljevanja štipendij do porabe sredstev, ki jih MDDSZ določi vsako leto posebej v razpisu. V njem je bilo določeno, koliko sredstev se lahko razdeli za štipendije na posameznih merilih. Kandidati so se morali odločiti, na katerem merilu želijo kandidirati, nato pa so jih razvrstili od najboljšega do najslabšega v skladu z metodologijo za razvrščanje kandidatov po posameznih merilih (Pravilnik o dodeljevanju štipendij, 2008). Ker je bilo premalo sredstev, da bi lahko vsi, ki so izpolnjevali merila, dobili štipendijo, se je kriterij močno zvišal (tabela 3). Mejna vrednost kriterija za odobritev štipendije je bila znana šele potem, ko se je izbirni postopek zaključil, torej šele čez nekaj mesecev po izteku razpisnega roka, kar je odstopalo od pretekle prakse. 
Tabela 3. Variabilnost kriterijev na posameznih merilih v letih 2008 do 2013

\begin{tabular}{|c|c|c|c|c|c|c|c|}
\hline \multirow[b]{2}{*}{ Merilo } & \multirow{2}{*}{$\begin{array}{l}\text { Pogoj za } \\
\text { kandidiranje }\end{array}$} & \multicolumn{6}{|c|}{ Meje po rangiranju } \\
\hline & & 2008 & 2009 & 2010 & 2011 & 2012 & 2013 \\
\hline Povprečna ocena OŠ & 4,5 & 4,87 & 4,91 & 4,92 & 5 & 5 & 5 \\
\hline Povprečna ocena SŠ & 4,1 & 4,92 & 4,75 & 4,78 & 4,85 & 4,91 & 5 \\
\hline Povprečna ocena VŠ & 8,5 & 9,43 & 9,45 & 9,62 & 9,75 & 9,72 & 9,76 \\
\hline Izjemni dosežek OŠ (št.točk) & 5 & 15 & 10 & 10 & 100 & 15 & 12,5 \\
\hline Izjemni dosežek SŠ (št. točk) & 5 & 40 & 15 & 60 & 45 & 10 & 20 \\
\hline Izjemni dosežek VŠ (št. točk) & 5 & 5 & 5 & 5 & 15 & 5 & 5 \\
\hline Zlata matura (število točk) & 30 & 30 & 30 & 30 & 30 & 30 & 30 \\
\hline
\end{tabular}

Zakon (ZŠtip) je določil le minimalne pogoje za kandidiranje za Zoisovo štipendijo, dejanski kriterij pa je bil znan šele po zaključku izbirnega postopka:

1. Za kandidate iz osnovnih šol: v zaključnem razredu OŠ najmanj povprečna ocena 4,5 ali več, hkrati pa so kandidati morali biti identificirani kot nadarjeni v skladu s Konceptom: odkrivanje in delo $\mathrm{z}$ nadarjenimi učenci $\mathrm{v}$ devetletni OS̆.

2. Za kandidate iz srednjih šol: povprečna ocena najmanj 4,1 in identifikacija kot nadarjenega dijaka v skladu $\mathrm{s}$ Konceptom vzgojno izobraževalnega dela z nadarjenimi dijaki v srednjem izobraževanju.

3. Za kandidate, ki so maturanti: izjemen splošni uspeh naziv zlati maturant.

4. Za kandidate iz višjih in visokih šol: povprečna ocena najmanj 8,5 ali uvrstitev med najboljših $5 \%$ študentov v posameznem letniku posameznega študijskega programa.

5. Za kandidate z dosežki ne glede na letnik izobraževanja: izjemni dosežek na posameznem področju družbenega življenja.

Za izjemni dosežek na posameznem področju družbenega življenja se je štelo: najvišja mesta na državnem tekmovanju; priznanja za najboljše raziskovalne naloge; udeležba in najvišja mesta na mednarodnem tekmovanju po predhodnem izboru na državnem tekmovanju na področju znanstvenoraziskovalne dejavnosti, razvojne dejavnosti, umetnosti in športa; nagrajeno znanstvenoraziskovalno delo na državni ali mednarodni ravni; objava znanstvenoraziskovalne naloge $\mathrm{v}$ strokovni reviji ali zborniku; drugi izjemni dosežki.

Povprečna ocena se je izračunala na dve decimalni mesti natančno. Večanje števila kandidatov in zmanjšanje sredstev za štipendije (slika 3) je privedlo do bistvene zaostritve kriterijev pri skoraj vseh merilih (tabela 3 ).

Ker ni bilo mogoče vnaprej predvideti števila kandidatov, ki bodo kandidirali na posameznih merilih, je bilo težko določiti ustrezne deleže sredstev na posameznih merilih. Podatki za šolsko leto 2008/09, ko so bile prvič podeljene Zoisove štipendije po novem zakonu, kažejo, da je bilo na vseh stopnjah izobraževanja glavno merilo učni uspeh in pri srednješolcih tudi merilo uspeh na maturi, ki je predstavljalo edino merilo, za katero je bilo dovolj rezerviranih sredstev za vse kandidate (tabela 4).

Zaradi zmanjšanja sredstev po letu 2010 se je kriterijska meja po končani razvrstitvi kandidatov močno dvignila pri vseh merilih (razen na merilu zlati maturant), pri merilu povprečna ocena v OŠ celo do maksimalne možne vrednosti (povprečna ocena 5,0). Tak postopek je bil sicer dokaj enostaven za izvedbo, v praksi pa krivičen, ker ni upošteval razlik v zahtevnosti posameznih izobraževalnih programov,

Tabela 4. Razdelilnik sredstev za Zoisove štipendije v javnem pozivu v šll. 2008/09, odstotni delež po merilu, meje po rangiranju in število podeljenih štipendij

\begin{tabular}{|c|c|c|c|c|c|}
\hline Skupina & $\begin{array}{l}\text { Odstotni delež } \\
\text { sredstev }\end{array}$ & $\begin{array}{l}\text { Merilo uveljavljanja } \\
\text { pravice }\end{array}$ & $\begin{array}{c}\text { Odstotni delež } \\
\text { sredstev po merilu }\end{array}$ & Meje po rangiranju & $\begin{array}{l}\text { Število podeljenih } \\
\text { štipendij }\end{array}$ \\
\hline \multirow[t]{3}{*}{ OŠ } & $50 \%$ & Povprečna ocena & $45 \%$ & 4,87 & 1595 \\
\hline & & Izjemni dosežek & $5 \%$ & 15 točk & 164 \\
\hline & & Povprečna ocena & $7 \%$ & 4,92 & 201 \\
\hline \multirow[t]{3}{*}{ SŠ } & $20 \%$ & Izjemni dosežek & $2 \%$ & 40 točk & 66 \\
\hline & & Zlata matura & $11 \%$ & 30 točk & 213 \\
\hline & & Povprečna ocena & $17 \%$ & 9,43 & 274 \\
\hline \multirow[t]{2}{*}{ VŠ } & $30 \%$ & Izjemni dosežek & $3 \%$ & 5 točk & 57 \\
\hline & & Najuspešnejših 5 \% & $10 \%$ & $1,14^{*}$ & 185 \\
\hline VSI & & & & & 2755 \\
\hline
\end{tabular}

Opombe: OŠ - kandidati iz osnovnih šol, Sك̆ - kandidati iz srednjih šol, VŠ - kandidati iz visokih šol.

*Količnik med povprečno oceno vlagatelja in povprečno oceno letnika študijskega programa. 


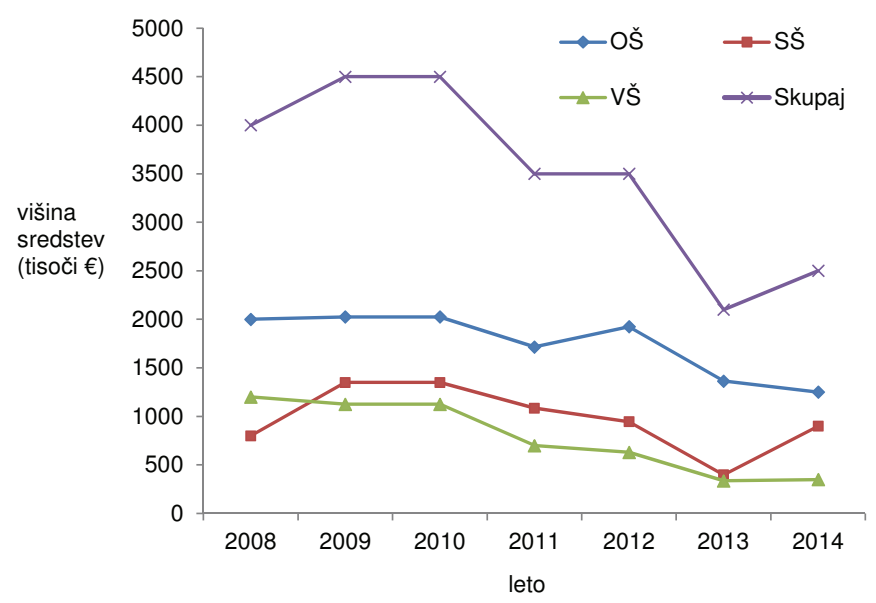

Slika 3. Višine sredstev za Zoisove štipendije in za posamezne skupine kandidatov iz OŠ, SŠ in VŠ v letih 2008 do 2014 (v tisočih evrov).

kar je bilo ugotovljeno že v evalvacijski študiji starih Zoisovih štipendij. Poleg tega se tudi ni upoštevalo, da so možnosti na posameznih študijskih programih različne za doseganje izjemnih dosežkov in nagrad. V prvih letih so bili favorizirani kandidati s športnimi dosežki.

ZŠtip je zaostril tudi pogoje za ohranitev Zoisove štipendije, in sicer se je pri študentih zahtevana povprečna ocena zvišala na 8,5 , pri dijakih pa na 4,1 . Zoisovo štipendijo je bilo možno ohraniti tudi s pomočjo javno priznanega izjemnega dosežka (ne glede na povprečno oceno), ki pa je na visokošolski stopnji izobraževanja veliko težje dosegljiv kot v srednji šoli. Nova, zaostrena merila za ohranitev štipendije so veljala tudi za »stare« Zoisove štipendiste, ki so nadaljevali izobraževanje na višji zahtevnostni stopnji, kar je povzročilo, da jih je mnogo ostalo brez štipendije na prehodu iz srednje šole na univerzo in na prehodu iz prve na drugo bolonjsko stopnjo. Le Zoisovi štipendisti, ki so bili vpisani v enoviti

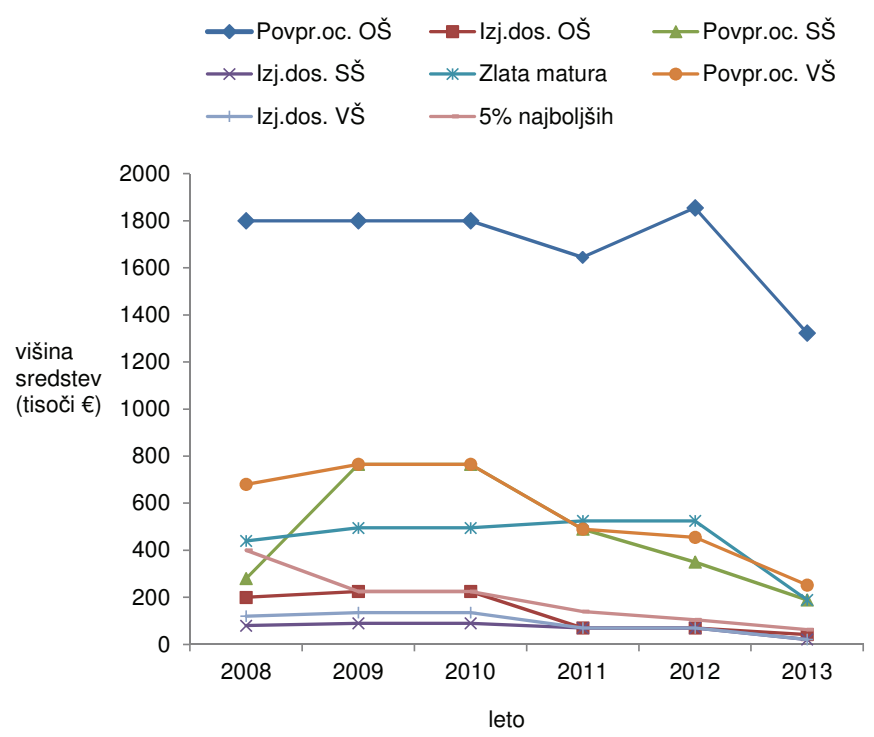

Slika 4. Spreminjanje višine sredstev po posameznih merilih od 2008 do 2013 (v tisočih evrov). magistrski študij pred letom 2008, so lahko prejemali Zoisovo štipendijo do konca študija pod prejšnjimi, blažjimi pogoji za ohranitev štipendije.

MDDSZ je za nove Zoisove štipendije v prvih treh letih najprej namenil več sredstev (4,5 milijona evrov), nato pa je štipendijska sredstva močno skrčil (slika 3), kar je bilo posledica gospodarske in finančne krize (slika 3). Dejstvo je, da so se najbolj zmanjšala sredstva za Zoisove štipendisteštudente (od 1,2 milijona evrov v študijskem letu 2008/09 na 350.000 evrov v študijskem letu 2014/15).

Največ sredstev (v višini 1,8 milijona eurov) je bilo namenjenih za merilo povprečna ocena $\mathrm{v}$ OŠ, dosti manj za merilo povprečna ocena SS̆ in VŠ, nato za zlate maturante, najmanj pa za kandidate z izjemnimi dosežki (slika 4). Presenetljivo je, da so se vsa leta stalno zmanjševala sredstva za vrhnjih $5 \%$ najboljših študentov (od 400.000 evrov v letu 2008 na 63.000 evrov v letu 2013). Obljube o bistveni spremembi Zoisovega štipendiranja $\mathrm{v}$ korist študentov, $\mathrm{s}$ katero so zagovarjali zakon o štipendiranju leta 2007, torej niso izpolnili.

\section{Merila za Zoisovo štipendijo v letu 2014}

S sprejetjem novega štipendijskega zakona (ZŠtip-1), ki je začel veljati s 1.1.2014, se je spet vse spremenilo: pogoji kandidiranja, način rangiranja kandidatov in tudi višina štipendije (ukinjen je bil dodatek na uspeh in dodatek glede na dohodek v družini štipendista). ZŠtip-1 je v 21. členu podal novo opredelitev namena Zoisovih štipendij: Zoisova štipendija je namenjena dijakom in študentom kot spodbuda za doseganje izjemnih dosežkov in s tem ustvarjanje dodane vrednosti na področju znanja, raziskovanja, razvojne dejavnosti in umetnosti. Med temi področji pa ni več področja športa, saj se športni dosežki po novem več ne štejejo med izjemne dosežke, kar je že sprožilo kritike s strani športnih organizacij (Žišt, 2014). Najnovejši pogoji za pridobitev Zoisove štipendije so sledeči:

Zoisovo štipendijo za izobraževanje lahko pridobi dijak, ki je dosegel izjemni dosežek in je:

- v zaključnem razredu osnovne šole dosegel povprečno oceno najmanj 4,70 - za dijaka v prvem letniku neposredno po prehodu iz osnovne šole na višjo raven izobraževanja ali

- imel v predhodnem šolskem letu glede na šolsko leto uveljavljanja štipendije $\mathrm{v}$ srednji šoli povprečno oceno najmanj 4,10 - za dijaka od vključno drugega letnika dalje.

Zoisovo štipendijo za izobraževanje lahko pridobi študent, ki je dosegel izjemen dosežek in je:

- zlati maturant ali je imel v zaključnem razredu srednje šole povprečno oceno najmanj 4,10 - za študenta $\mathrm{v}$ prvem letniku neposredno po prehodu iz srednje šole na višjo raven izobraževanja ali

- imel v predhodnem študijskem letu glede na študijsko leto uveljavljanja štipendije na višješolskem ali visokošolskem izobraževanju povprečno oceno najmanj 8,50 ali je bil v 
višješolskem ali visokošolskem izobraževanju glede na doseženo povprečje uvrščen med najboljših pet odstotkov v svoji generaciji - za študenta od drugega letnika dalje.

Bistvena novost je hkratni pogoj izjemnega dosežka in uspeha za vse kandidate, kar pomeni zaostritev meril in posledično zmanjšanje števila kandidatov za Zoisovo štipendijo. Ti pogoji so zelo podobni razpisnim pogojem za Zoisovo štipendijo, ki so veljali za srednješolce in študente $\mathrm{v}$ obdobju 1996 - 2007, s tem da so pri pogoju učnega uspeha še bolj ostri. Zaostritev merila povprečne ocene za osnovnošolce na 4,7, ki velja tudi za kandidate $\mathrm{z}$ izjemnimi dosežki je pretirana, saj do sedaj tega dodatnega pogoja učnega uspeha ni bilo. Ta dodatni pogoj prizadane predvsem specifično nadarjene, ki močno izstopajo samo na enem področju, in fante, ker težje izpolnijo pogoj visoke povprečne ocene. Tudi način rangiranja kandidatov se je spremenil. Kandidati se po novem razvrščajo v tri skupine (OŠ, SŠ, VŠ), v vsaki skupini pa po vrsti najprej na podlagi merila izjemnih dosežkov, nato zlati maturanti in na koncu na podlagi merila povprečne ocene. Na ta način so zvišali težo izjemnega dosežka in znižali težo povprečne ocene, kar je bolj v skladu s temeljnim namenom Zoisovih štipendij. Zato je nenavadno, da se je kot pogoj za kandidiranje pri osnovnošolcih povprečna ocena zvišala na 4,7, kot da bi želeli dodatno selekcionirati kandidate z izjemnimi dosežki. Zaradi neizpolnjevanja pogoja učnega uspeha je tako marsikateri nadarjeni učenec z izjemnimi dosežki v OŠ ostal brez nje, čeprav bi kasneje v srednji šoli lahko zadostil pogoju za ohranitev štipendije (povprečna ocena 4,1). Izjemni dosežki so sedaj nekoliko bolj natančno opredeljeni in ovrednoteni. $\mathrm{V}$ novem zakonu ni več pogoja, da mora biti kandidat identificiran kot nadarjen $\mathrm{v}$ skladu $\mathrm{s}$ Konceptom odkrivanja in dela $\mathrm{z}$ nadarjenimi v OŠ in S $\breve{S}$. To je razumljivo, saj je identificiranih nadarjenih bistveno več kot pa odličnih učencev z izjemnimi dosežki, zato status nadarjenosti ne predstavlja neke dodane vrednosti pri samem izboru.

Vendar so tudi nova merila pomanjkljiva. Pri povprečni oceni se ohranja nediferenciranost glede na zahtevnost študijskih programov, poleg tega pa problem predstavlja zahteva, da morajo stari Zoisovi štipendisti ponovno izpolnjevati začetne pogoje za dodelitev štipendije na prehodu na višjo stopnjo izobraževanja, kar predstavlja visoko oviro, zlasti na tistih študijskih programih, kjer takih dosežkov na prvi bolonjski stopnji še ni mogoče pričakovati. O tem priča tudi zgodba ene od zavrnjenih Zoisovih štipendistk v letu 2014. Nekdanja Zoisova štipendistka je imela štipendijo osem let, nato pa jo je izgubila na prehodu iz dodiplomskega na podiplomski študij, ker ni izpolnila pogoja izjemnega dosežka. V osnovni šoli je bila super odličnjakinja in prejela osem zlatih priznanj, v srednji šoli je bila prav tako ves čas odlična, na maturi je dosegla vseh 34 točk, na študiju kemije je imela povprečje vseh ocen 9,5 , v zadnjem letu je dosegla celo povprečje 9,8 , nato pa je izgubila štipendijo, ker še ni imela izjemnega dosežka po končani prvi stopnji bolonjskega programa (Merljak, 2014). Očitno imajo tudi novi pogoji težave, saj lahko formalno navidezna enakost zakonskih določb za vse kandidate povzroči v praksi velike krivice. Ponovno se je zgodilo, da predlagatelj novega zakona ni predhodno izvedel potrebnih simulacij spremembe meril v praksi, popravke zakona pa je seveda težko na hitro narediti. Premalo se je upoštevalo tudi dejstvo, da študij na prvi bolonjski stopnji še ne omogoča doseganja izjemnih dosežkov (Merljak, 2014). Zgodba iz leta 2008, ko je mnogo starih Zoisovih štipendistov izgubilo štipendijo na prehodu iz srednje šole na univerzo in iz prve na drugo bolonjsko stopnjo, ker niso izpolnjevali novih meril in kriterijev, se je leta 2014 ponovila po sprejetju ZŠtip-1. Tak sistem štipendiranja najuspešnejših dijakov in študentov ne prispeva k njihovemu razvoju, ampak pri marsikaterem povzroča nepotrebne stiske in razočaranja (Mlakar, 2012).

V letu 2014 je bilo število novo podeljenih Zoisovih štipendij manjše kot v obdobju od 2008 do 2013. Najbolj pade v oči majhno število podeljenih štipendij v skupini SŠ in VŠ, kjer se je število prepolovilo. Zmanjšalo se je tudi število podeljenih štipendij na prehodu iz osnovne v srednjo šolo, in sicer za več kot 700 . Podatki o številu Zoisovih štipendistov $\mathrm{v}$ posameznih letnikih srednješolskega in visokošolskega študija kažejo, da so vprašljiva tudi merila za ohranitev Zoisove štipendije. Po podatkih Statističnega urada RS se v obdobju od leta 2008 do 2013 število prejemnikov Zoisovih štipendij vztrajno zmanjšuje, kar pomeni, da je več Zoisovih štipendistov štipendijo izgubilo, kot pa jo je na novo pridobilo (tabela 5).

Podobno sliko dobimo tudi pri študentih (tabela 6), kjer so vključeni tudi »stari« Zoisovi štipendisti, ki so štipendijo pridobili še po starih predpisih pred letom 2007 in jo prejemali do zaključka izobraževanja na dodiplomskem študiju.

Presenetljivi in skrb vzbujajoči so podatki v vrstici ABS, ki kažejo, kako je po študijskem letu 2011/12 upadlo število Zoisovih štipendistov absolventov skoraj za polovico (iz več kot 1300 na 691). Po študijskem letu 2011/12 je prišlo

Tabela 5. Zoisovi štipendisti dijaki v obdobju 2008 - 2014 v posameznih letnikih in skupno število

\begin{tabular}{|c|c|c|c|c|c|c|c|}
\hline Letnik & $2008 / 09$ & $2009 / 10$ & $2010 / 11$ & $2011 / 12$ & $2012 / 13$ & $2013 / 14$ & $2014 / 15$ \\
\hline Prvi & 1759 & 2040 & 1458 & 1435 & 1541 & 1566 & 1068 \\
\hline Drugi & 1274 & 1580 & 1697 & 1336 & 1292 & 1319 & 1408 \\
\hline Tretji & 1243 & 1430 & 1569 & 1665 & 1236 & 1236 & 1262 \\
\hline Četrti & 1422 & 1433 & 1554 & 1601 & 1598 & 1194 & 1206 \\
\hline Peti & 9 & 10 & 19 & 11 & 13 & 9 & 4 \\
\hline Skupaj & 5707 & 6493 & 6297 & 6048 & 5680 & 5324 & 4948 \\
\hline
\end{tabular}

Opomba: Peti letnik pomeni vpisani v peti letnik v srednješolskih programih $3+2$. 
Tabela 6. Zoisovi štipendisti študenti v obdobju 2008 - 2014 v posameznih letnikih in skupno število

\begin{tabular}{|c|c|c|c|c|c|c|c|}
\hline Letnik & $2008 / 09$ & $2009 / 10$ & $2010 / 11$ & $2011 / 12$ & $2012 / 13$ & $2013 / 14$ & $2014 / 15$ \\
\hline Prvi & 1184 & 1652 & 1686 & 1808 & 1975 & 2039 & 385 \\
\hline Drugi & 1637 & 1156 & 1081 & 1053 & 1056 & 1234 & 1206 \\
\hline Tretji & 1532 & 1578 & 1026 & 909 & 761 & 737 & 784 \\
\hline Četrti & 1220 & 1317 & 1059 & 673 & 273 & 239 & 257 \\
\hline Peti & 362 & 393 & 426 & 412 & 221 & 195 & 168 \\
\hline Šesti & 156 & 165 & 173 & 194 & 136 & 122 & 137 \\
\hline ABS & 1179 & 1317 & 1392 & 1387 & 894 & 594 & 691 \\
\hline Skupaj & 7270 & 7578 & 6843 & 6436 & 5316 & 5160 & 3628 \\
\hline
\end{tabular}

Opomba: ABS so vpisani v absolventski staž ali izkoriščajo pravico do enoletnega podaljšanega študentskega statusa oziroma do dodatnega študijskega leta po preteku izobraževalnega programa.

do zamenjave »starih« Zoisovih štipendistov, ki so ohranili pravico do Zoisove štipendije še po prejšnjih predpisih pred letom 2007, z novimi Zoisovi štipendisti, med katerimi pa je le polovica ohranila štipendijo do konca študija. Tudi skupno število vseh Zoisovih štipendistov-študentov se zmanjšuje, čeprav so ob predlogu zakona o štipendiranju leta 2007 obljubljali, da bodo študentom podelili več Zoisovih štipendij kot prej na Zavodu. Prvi upad se zgodi že po prvem letniku študija, ko več kot tretjina Zoisovih štipendistov ne izpolni pogoja uspeha za ohranitev štipendije $\mathrm{v}$ drugem letniku študija (povprečna ocena najmanj 8,5 ali izjemni dosežek). Drugi upad pa se zgodi po zaključku prve bolonjske stopnje, ko štipendist nadaljuje z izobraževanjem na drugi bolonjski stopnji. Zoisove štipendije so se po letu 2008 tako podeljevale večinoma le za kratko obdobje enega ali kvečjemu nekaj let. Vprašati se je treba, ali so se uresničili nameni, ki so si jih zastavili pripravljalci ZŠtip leta 2007, da naj Zoisove štipendije služijo spodbujanju tistih potencialov, ki jih država potrebuje za preboj med uspešne. Očitno je, da je več kot polovica tistih, ki so jih najprej prepoznali kot najbolj obetajoče potenciale v državi, že čez nekaj let izgubila podporo. Takšna politika štipendiranja je seveda s stališča investicije v vrhunske kadre vprašljiva, saj se realizacija nadarjenih ne povečuje, kar je glavna kritika sistema Zoisovega štipendiranja po letu 2008. Slovenija si ne more privoščiti tako selektivnega načina izbora štipendistov, kot si ga lahko morda v državah s stokrat večjo populacijo. Še kako utemeljeno je bilo priporočilo v evalvacijski študiji, da morajo pri oblikovanju strokovnih meril za podeljevanje Zoisovih štipendij sodelovati strokovnjaki, ki poznajo problematiko, in da naj se pred uveljavitvijo morebitnih sprememb meril in pogojev za dodelitev in ohranitev Zoisove štipendije predhodno naredi simulacijo, kar pa se (ponovno) ni zgodilo.

\section{Bistvene pomanjkljivosti sedanje ureditve Zoisovega štipendiranja iz leta 2014}

Merila za izbor Zoisovih štipendistov in tudi za ohranitev Zoisove štipendije so se v ZŠtip-1 zaostrila, pri tem pa se je namen Zoisovih štipendij zreduciral na »spodbujanje doseganja izjemnih dosežkov in ustvarjanje dodane vrednosti na področju znanja, raziskovanja, razvojne dejavnosti in umetnosti« (21. člen). Razlogi za zaostritev meril niso pojasnjeni. Na tem mestu lahko navedem samo nekaj pomanjkljivosti ureditve Zoisovih štipendij po letu 2013:

1. V ZŠtip-1 nadarjeni sploh niso več omenjeni, saj se je namen zreduciral zgolj na spodbujanje izjemnih dosežkov in učne uspešnosti. Tako so se pripravljalci zakona pravzaprav izognili problemu opredelitve nadarjenosti, s tem pa povsem zanemarili osnovni namen štipendij za nadarjene - spodbujanja razvoja nadarjenih.

2. Pri vrednotenju izjemnih dosežkov se upoštevajo samo dosežki nadpovprečno uspešnih učencev, dosežki ostalih učencev, ki ne izpolnjujejo pogoja učnega uspeha, pa se ne obravnavajo ne glede na njihovo izjemnost. To pomeni, da ima učni uspeh večjo težo kot izjemni dosežek in da so v prednosti t. i. univerzalno nadarjeni z odličnim uspehom ter prikrajšani vsi specifično nadarjeni, ki izkazujejo nadarjenost le na posameznem področju (npr. matematični talenti, umetniški talenti, literarno nadarjeni itd.) in nimajo splošnega odličnega uspeha.

3. Merila so določena arbitrarno in so zato strokovno vprašljiva. Točkovanje izjemnih dosežkov ni ustrezno obteženo in ne upošteva različnih možnosti, ki jih imajo kandidati za doseganje izjemnih dosežkov na različnih stopnjah izobraževanja - največje možnosti imajo kandidati v osnovnih šolah, najmanjše na fakultetah. Pa tudi med študijskimi programi obstajajo razlike glede možnosti za doseganje izjemnih dosežkov; na primer na medicini so možnosti zelo omejene na redke izbrance.

4. Tudi ta zakon ni odpravil pomanjkljivosti kriterija enake povprečne ocene za vse študijske programe ne glede na njihovo težavnost, kar pomeni, da so prikrajšani kandidati oziroma prejemniki Zoisovih štipendij na bolj zahtevnih študijskih programih.

5. Zoisove štipendije dejansko predstavljajo samo nagrado za trenutne dosežke in učno uspešnost in nimajo razvojne funkcije, saj se jo zaradi ostrih kriterijev za ohranitev težko obdrži do konca študija. Tovrstna izguba štipendije prizadane zlasti uspešne študente z nižjim SES.

6. V primerjavi s kadrovskimi štipendijami Zoisove štipendije nimajo nobene kadrovske funkcije. V sistem Zoisovih štipendij bi bilo smiselno vnesti elemente 
povezovanja $\mathrm{z}$ delodajalci, vsaj za tista področja, ki so za državo prioritetna (IKT, okoljevarstvene tehnologije, biotehnologija, farmacija in živilstvo, proizvodnja naprednih materialov, industrijska kemija, trajnostna gradnja; Stanovnik, 2008), seveda pa tudi z vsemi drugimi, ki imajo vizijo globalnega razvoja in si želijo sodelovanja s Zoisovimi štipendisti.

7. Sedanja ureditev Zoisovega štipendiranja paradoksalno ne povečuje deleža aktualiziranih nadarjenih. Mnogi nadarjeni v konkurenci z zelo uspešnimi do nje sploh ne pridejo, če pa že, jih polovica med njimi štipendijo do konca študija izgubi. Osnovni problem ostaja nediferenciranost pogojev, ki veljajo za vse enako ne glede na razlike v zahtevnosti študijskih programov in različnih možnosti za doseganje izjemnih dosežkov.

\section{Predlog potrebnih izboljšav Zoisovega štipendiranja}

Ker se napovedani pozitivni učinki spremembe Zoisovega štipendiranja ne uresničujejo, ampak gredo celo v nasprotno smer (npr. zmanjšanje števila Zoisovih štipendistov in znižanje višine štipendije, s čimer se zmanjšuje tudi pomen štipendije), je prišel čas, da se ponovno razpravlja o temeljnem namenu Zoisovih štipendij, tj. podpora nadarjenim pri aktualizaciji njihovih potencialov, in da se ponovno izvede reformo Zoisovega štipendiranja. Prepričan sem, da je namen sedanjih Zoisovih štipendij - spodbujanje izjemnih dosežkov - postavljen preozko in po določilih sedanjega zakona (ZŠtip-1) težko izvedljiv. Pravi namen podeljevanja Zoisovih štipendij mora postati spodbujanje ustvarjalnih in drugih aktivnosti nadarjenih, ki lahko vodijo k različnim izjemnim dosežkom (ni pa nujno), ki spodbujajo nadarjene v poglobljen študij na področjih, ki jih zanimajo, in ki lahko kasneje vodijo k njihovi uspešni delovni ali raziskovalni karieri. Tako bi Zoisove štipendije dobile večjo razvojno funkcijo. Seveda pa se spodbujanje ustvarjalnih dejavnosti lahko usmerja na posamezna področja, ki so razvojno prioritetna, pri čemer bi lahko Zoisove štipendije pridobile elemente kadrovske funkcije (npr. opravljanje učne in delovne prakse v sodelovanju $\mathrm{z}$ zainteresiranimi delodajalci in podjetniki, vključevanje $\mathrm{v}$ raziskovalne skupine in sodelovanje pri različnih projektih, kjer bi lahko prispevali svoje ideje in zamisli). Tak namen Zoisovih štipendij se lahko uresniči, če pri njem sodelujejo trije podsistemi:

a. vzgojno-izobraževalne organizacije, kjer poteka odkrivanje in delo z nadarjenimi,

b. podporno okolje, v katerem se izvajajo ustvarjalne dejavnosti v najširšem pomenu besede, ki so predhodno dobro načrtovane in selekcionirane,

c. delodajalci in raziskovalne ustanove, ki jih zanima sodelovanje s Zoisovimi štipendisti.

Vsak od teh podsistemov ima svojo specifično vlogo in pomen pri uresničevanju namena Zoisovih štipendij:

1. Vzgojno-izobraževalne organizacije bi morale pravočasno prepoznati nadarjene in jim omogočiti razvoj njihovih potencialov v tolikšni meri, da bi ob koncu osnovne šole bila možna zanesljiva identifikacija nadarjenih na osnovi njihovih dosežkov v daljšem obdobju. Zoisova štipendija naj bi imela proaktivno funkcijo in zato dodeljena kandidatom, ki so jih že v šoli identificirali kot nadarjene in bi Zoisovo štipendijo potrebovali za poglabljanje interesa na določenem področju, vpis v dodatne oblike dela $\mathrm{z}$ nadarjenimi in izvajanje konkretnih projektov in ustvarjalnih dejavnosti.

2. Podporno okolje sestavljajo vse organizacije, ki izvajajo programe spodbujanja razvoja nadarjenih, spodbujanja ustvarjalnosti in inovativnosti, ter izvajalci raziskovalnih dejavnosti, ki želijo delati z mladimi nadarjenimi ljudmi. Takšno podporno okolje lahko organizirajo srednje šole in fakultete, lahko pa tudi druge organizacije in podjetja. Izvajalci dejavnosti bi morali skrbeti za kakovost programov in njihovo stalno posodabljanje.

3. Delodajalci, ki so zainteresirani za sodelovanje s Zoisovimi štipendisti v času šolanja in pri kasnejšem zaposlovanju, ki vključuje javni in privatni sektor, bi se povezali $\mathrm{v}$ združenje perspektivnih delodajalcev in omogočali Zoisovim štipendistom različne oblike sodelovanja, kot so npr. opravljanje delovne prakse, nudenje aplikativnih tem za izdelavo diplomskih, magistrskih nalog, možnost uporabe laboratorijev in raziskovalne opreme itd. ter jih tako spoznavali in usmerjali na področja dela, kjer bi se lahko kasneje zaposlili. Ob tem bi nudili pomembne informacije o svetu dela in področjih, ki so zanimiva oziroma prioritetna za prihodnji razvoj države in jih seznanjali s svojimi kadrovskimi potrebami.

Zoisove štipendije bi torej na eni strani bile namenjene spodbujanju nadarjenih $\mathrm{k}$ ustvarjalnim in drugim aktivnostim $\mathrm{v}$ funkciji razvoja nadarjenosti, na drugi strani pa bi omogočale boljše povezovanje med različnimi podsistemi in te aktivnosti deloma tudi sofinancirale. Pogoj za uspešno izvedbo reforme Zoisovega štipendiranja je torej ta, da se na državni ravni oblikuje organ, ki bo povezal vse tri podsisteme, kar bi se lahko izvedlo $\mathrm{z}$ ustanovitvijo posebnega sklada za Zoisove štipendije. Glede na količino sredstev, ki se namenjajo za Zoisove štipendije, je ustanovitev sklada za Zoisove štipendije nujna. Od sedanje pasivne vloge razdeljevanja proračunskih sredstev za Zoisove štipendije bi moral novi sklad izvajati aktivno vlogo zbiranja teh sredstev iz različnih virov (proračun, sredstva delodajalcev, sredstva skladov EU idr.).

V nadaljevanju predstavljam nujne spremembe, ki bi bile potrebne za uresničitev tega namena:

Sprememba postopka in meril za dodelitev in za ohranitev Zoisove štipendije. Štipendija je namenjena identificiranim nadarjenim, ki izpolnjujejo merilo izjemnega dosežka (ki se določi z empirično analizo) in imajo ustrezno visoko povprečno oceno iz vseh predmetov (ki se določi na podlagi empirične analize) ali iz glavnih predmetov za določeni izobraževalni program. Kandidat obvezno navede področje dejavnosti, na katerem se želi izpopolnjevati. Pri študentih se študijski uspeh izračuna na podlagi z-vrednosti povprečne ocene glede na povprečje študijskega programa. Razvrstitev aktivnosti $\mathrm{v}$ posamezna področja ali polja dejavnosti je predlagal že Francoys Gagné (2008) v svoji teoriji diferenciranega modela razvoja talentov. Predlagam, da bi za osnovo vzeli že znano Hollandovo klasifikacijo poklicnih 
okolij (RIASEC; Holland, 1997), tako da bi kandidat za Zoisovo štipendijo že ob vlogi izbral tudi področje dejavnosti, na katerem namerava razvijati svojo nadarjenost. Ta področja bi tako bila: 1. akademsko (pokriva področja jezikov, matematike, naravoslovja, družboslovja, humanistike) in poklicni tip I (angl. investigative); 2. umetniško (vsa področja umetniškega ustvarjanja) in tip A (angl. artistic); 3. socialno (zdravstveno in izobraževalno področje, delo v skupnosti) in tip S (angl. social); 4. podjetniško (management, trženje) in tip E (angl. entrepreneurial); 5. tehnično (gradbeništvo, strojništvo, tehnologija, računalništvo, elektronika) in tip R (angl. realistic); 6. ekonomsko (finančno in računovodsko področje, javna uprava) in tip C (angl. clerical). Kandidat bi torej moral $\mathrm{v}$ svoji vsakoletni vlogi za štipendijo navesti področje dejavnosti, ki ga zanima, in v katerem namerava poglabljati svoje znanje in interes. Kandidat, ki ga zanima več področij, lahko navede več aktivnosti iz različnih področij, ker so možne tudi kombinacije področij. Tako bi lahko oblikovali profil Zoisovega štipendista, ki bi bil zanimiv tudi za delodajalce. Hkrati bi na vsakem področju razdelali vse možnosti za doseganje izjemnih dosežkov in Zoisov štipendist bi lahko izbral eno ali več področij, znotraj katerih bi iskal svoje možnosti in aktivnosti za realizacijo svojega talenta. Smiselno bi bilo spremljati interes delodajalcev in ga primerjati s področji dejavnosti, ki zanimajo Zoisove štipendiste.

Razvoj podpornega okolja. Podporno okolje niso samo številne možnosti za različna individualna ali skupinska tekmovanja na državni ravni, ampak gre lahko tudi za prave skupinske raziskovalne in druge projekte ter timsko delo. Del sredstev Zoisovega štipendiranja bi morali nameniti za spodbujanje razvoja dodatnih oblik dela z nadarjenimi, predvsem obogatitvenih programov, ki niso del rednega pouka, poletnih raziskovalnih taborov in drugih aktivnosti med letom, kjer lahko pridejo v stik z vrhunskimi mentorji, laboratoriji, delavnicami, in kjer bodo lahko razvijali svojo ustvarjalnost. Šele v takem podpornem okolju lahko kasneje upravičeno pričakujemo, da bodo Zoisovi štipendisti dosegali izjemne dosežke. EU je pripravljena sofinancirati dejavnosti, ki so namenjene nadarjenim, pri tem pa se ne sme omejiti samo na različna tekmovanja in preverjanja znanj, ampak načrtno razvijati različne aktivnosti namenjene nadarjenim. Tako bi lahko tudi sklad finančno podprl taka prizadevanja $\mathrm{z}$ ustreznimi razpisi za izvajalce aktivnosti in jih pri tem v določeni meri usmeril na nova področja (npr. povezovanje podjetništva, znanosti in tehnologije), kjer bi lahko inovativnost nadarjenih prišla do izraza. Kako bi lahko Zoisova štipendija to omogočila? S tem, da bi se del štipendije izplačeval v obliki vavčerja, s katerim bi lahko Zoisov štipendist pokril stroške za posamezne aktivnosti (vpisnina, kotizacija itd.) do določene vrednosti štipendije. Že mesečni znesek 50 ali več evrov bi na letni ravni predstavljal pomembno finančno injekcijo za katerokoli dejavnost. Seveda bi bilo treba preučiti pravo višino Zoisove štipendije, ki jo štipendist dobi delno izplačano in delno $\mathrm{v}$ obliki vavčerja, ki ga lahko koristi za neko dejavnost. Ne smemo pozabiti, da bi lahko v štipendijski sklad za financiranje v obliki vavčerjev prispevala tudi razna podjetja, ki bi s tem tržila svoje proizvode, dejavnosti, ali pa se zgolj marketinško postavljala s krilatico "Podpiramo talente", s čimer bi se povečala sredstva za dejavnosti Zoisovih štipendistov. Na skladu bi v ta namen zaposlili osebo, ki bi se ukvarjala samo $\mathrm{s}$ področjem razvoja nadarjenih in zbirala vse informacije o aktivnostih in razpisih različnih izvajalcev. Zoisov štipendist bi lahko bil samo tisti, ki je dovolj aktiven, in ki lahko tudi pokaže rezultate svojega dela na različnih projektih, in to ne samo na področju znanstvenega raziskovanja, ampak tudi na umetniškem, socialnem ali podjetniškem področju. V Sloveniji poteka zelo intenzivno razvijanje programov za spodbujanje inovativnosti in podjetništva, ki bi bili primerni tudi za Zoisove štipendiste s podjetniškim interesom (tip E).

Povezovanje Zoisovih štipendistov $\mathrm{z}$ delodajalci $\mathrm{v}$ času izobraževanja. To bi se lahko sistematično uredilo z uvedbo učne ali delovne prakse v podjetjih in na univerzah, ki bi za to izrazila interes. Tako kot je npr. Univerza v Novi Gorici na spletu objavila svojo ponudbo "Naslovi predavanj, delavnic in naravoslovnih dni, ki jih organizirajo za srednje šole" (UNG, 2014), bi lahko naredile vse univerze v Sloveniji. Vavčerski sistem bi seveda te aktivnosti še bolj spodbudil, razvili bi se lahko noviprogrami in aktivnosti sodelovanja med univerzami, delodajalci in Zoisovimi štipendisti. V praksi bi sodelovanje potekalo prek spletnega povezovanja $\mathrm{z}$ delodajalci po zgledu nekdanje e-Borze Zoisovih štipendistov, ki je delovala na Zavodu za zaposlovanje. Povezave med Zoisovimi štipendisti študenti in delodajalci bi se lahko spodbujalo z objavljanjem razpisov za raziskovalne naloge, projekte itd. Novi zakon o štipendiranju bi moral omogočiti spremljanje Zoisovih štipendistov tudi po zaključku študija, tudi v obdobju razvoja delovne kariere in iskanja ustrezne zaposlitve (vsaj do 35. leta). Tu lahko pomembno vlogo odigra združenje perspektivnih delodajalcev v okviru sklada za Zoisove štipendije. To funkcijo naj bi sicer opravljala univerza in visokošolski zavodi, vendar tega ne izvajajo načrtno. Evalvacija Zoisovega štipendiranja iz leta 2004 je pokazala, da se je večina Zoisovih štipendistov (ki so bili Zoisovi štipendisti od leta 1986 do 1995) zaposlila v negospodarstvu, torej $\mathrm{v}$ javnem sektorju, ker se je takrat ta sektor pač širil, gospodarstvo pa krčilo. Danes je gospodarska situacija drugačna, zaposlovanje $v$ javnem sektorju je že nekaj let strogo restriktivno, medtem ko se gospodarstvo po krizi počasi pobira na noge in bo seveda $\mathrm{v}$ prihodnosti potrebovalo dobro izobražene kadre za svoj nadaljni razvoj. Verjetno je sedaj pravi čas, da se opozori na bolj premišljeno politiko zaposlovanja nadarjenih, znotraj katere bodo morali delodajalci, ki želijo uspeti v tekmovanju z zunanjimi trgi, zaposlovati in si sami vzgojiti svoje razvojne kadre. Po zgledu iz tujine, kjer pritegujejo nadarjene ljudi, bi morali tudi v Sloveniji narediti klimo, ki bo privlačna za perspektivne kadre, kamor lahko štejemo uspešne nadarjene ljudi. Pri tem je pomembno, da se zagotovi ustrezne pogoje za delo in zaposlitev na tistih področjih, ki so za Slovenijo prioritetna. Zato bi bilo smiselno, če bi v sodelovanju z Gospodarsko zbornico Slovenije in Obrtno zbornico Slovenije poiskali in združili vse pomembnejše delodajalce $z$ vizijo prihodnosti, ki želijo vlagati $\mathrm{v}$ pridobivanje inovativnih kadrov in to smatrjajo kot bistven pogoj za lastni razvoj. Združenju perspektivnih delodajalcev bi se lahko pridružili tudi manjši podjetniki, ki odpirajo visokotehnološka podjetja, in seveda različne raziskovalne organizacije in inštituti, ki bi lahko ponudili različne oblike sodelovanja s Zoisovimi štipendisti. Združenje bi lahko neposredno vplivalo na kadrovsko 
funkcijo Zoisovega štipendiranja $\mathrm{z}$ dodatnimi spodbudami, možnostmi opravljanja prakse, počitniškega dela, diplomskih nalog, magistrskih nalog itd.

Spodbujanje aktivnosti Zoisovih štipendistov $\mathrm{z}$ uvedbo vavčerjev. Po sedanji ureditvi je podeljevanje Zoisovih štipendij neodvisno od izobraževalnega programa kandidata za Zoisovo štipendijo, zaradi česar Zoisove štipendije nimajo nobene usmerjevalne funkcije. Če bi uvedli sistem vavčerjev bi bilo možno štipendijska sredstva delno usmerjati $\mathrm{z}$ namenom podpiranja tistih aktivnosti oziroma področij, ki so opredeljena kot prioritetna za gospodarski in tehnološki razvoj države. Štipendija bi torej morala biti sestavljena iz dveh postavk. En del štipendije dobi Zoisov štipendist izplačan na svoj transakcijski račun (osnovna Zoisova štipendija $\mathrm{z}$ morebitnimi dodatki), drugi del štipendije pa se virtualno zbira na posebnem računu, ki ga Zoisov štipendist lahko koristi le v obliki vavčerja za stroške aktivnosti, ki jih sam izbere in jih priporoča tudi sklad. Zoisov štipendist bi imel možnost vpogleda $v$ neizplačana del štipendije, ki ga lahko izkoristi v obliki vavčerja. Izvajalci bi se morali predhodno s svojimi programi prijaviti na sklad za sofinanciranje, po odobritvi ustreznosti programov in dogovorjene višine kotizacije pa bi se Zoisovi štipendisti v takšne aktivnosti lahko začeli prijavljati. Vavčerji bi se izvajalcem vnovčevali po koncu aktivnosti na podlagi poročila o izvedbi aktivnosti in potrjenega seznama udeležencev. Izdajanje vavčerjev in spremljanje višine porabljenih sredstev na računu štipendista bi bila naloga sklada. Če naj bo namen Zoisovih štipendij spodbujanje razvoja, je potrebno Zoisove štipendiste usmeriti v take aktivnosti, kjer se bodo lahko družili, izmenjevali izkušnje in ustvarjali pod vodstvom izkušenih mentorjev, kar vključuje aktivnosti in dejavnosti v okviru šolskih in tudi izvenšolskih dejavnosti (nadstandard). Pri tem je treba zagotoviti kvaliteto programov teh aktivnosti, kar bi bilo možno narediti s predhodno selekcijo teh aktivnosti na osnovi določenih kriterijev, predvsem glede kvalitete mentorskega kadra, pa tudi organiziranosti in programskih vsebin. Nujno je sodelovanje $z$ Ministrstvom za izobraževanje, znanost in šport ter Zavodom za šolstvo, in tudi ostalimi organizacijami izven šole, ki izvajajo ustvarjalne aktivnosti za mlade. Tako bi se lahko pripravil razpis projektov in programov za razvoj nadarjenih na različnih področjih (osnovni in nadaljevalni programi), v katerih se Zoisovi štipendisti skupaj z drugimi udeleženci povezujejo s potencialnimi delodajalci (nekaj zgledov na tem področju že imamo).

\section{Zaključek}

Zgodovinski pregled štipendiranja nadarjenih v Sloveniji je pokazal, da se je prvotni namen štipendiranja nadarjenih, tj. pomoč izrazito nadarjenim iz delavskih in kmečkih slojev (in kasneje tudi iz srednjega sloja), postopoma preoblikoval iz podpore nadarjenim k podpori uspešnim. Podobno kot so imeli pobudniki štipendiranja nadarjenih težave $\mathrm{z}$ oblikovanjem meril in kriterijev za izbor nadarjenih, se sedaj pojavljajo težave pri določitvi meril in kriterijev za izbor najuspešnejših. Ker je uspešnih učencev bistveno več kot je na razpolago sredstev za štipendije, imajo v praksi možnost za pridobitev Zoisove štipendije samo še odlični učenci, vsi ostali, ne glede na njihovo specifično nadarjenost in izjemne dosežke, pa ne. Tako pretirano spodbujanje storilnostne motivacije dejansko ovira razvoj notranje motivacije nadarjenih (Juriševič, 2012). Tudi vsi storilnostno usmerjeni nadarjeni niso $\mathrm{v}$ enakem položaju, ker so njihovi izjemni dosežki odvisni od kakovosti izobraževalnega programa (npr. priprav na tekmovanja, kakovosti učiteljev itd.) in različnih možnosti, ki jih imajo za doseganje izjemnega dosežka, kar še posebej velja za visokošolske programe. Glede na znano odvisnost učnega uspeha od SES družine (Toličič in Zorman, 1977), je mogoče trditi, da so sedanja merila $\mathrm{v}$ prid kandidatom, ki prihajajo iz družin z višjim SES, in da so prikrajšani nadarjeni iz socialno šibkih okolij. Ugotovitev, da se je število Zoisovih štipendistov študentov med letoma 2007 in 2014 zmanjšalo na polovico je alarmantna, saj kaže na to, da vsaj polovica nadarjenih $\mathrm{V}$ času študija ostaja brez finančne podpore. Reforma sedanjega Zoisovega štipendiranja je več kot nujna. Najprej pa je potrebno poenotiti izhodišče, da mora osnovni namen Zoisovega štipendiranja spet postati podpora nadarjenim pri razvoju njihovih potencialov, s posebnim poudarkom na spodbujanju ustvarjalnih in drugih aktivnosti, ki lahko vodijo $\mathrm{k}$ izjemnim dosežkom, ki spodbujajo nadarjene v poglobljen študij na področjih, ki jih zanimajo, in ki lahko kasneje vodijo $\mathrm{k}$ njihovi uspešni delovni ali raziskovalni karieri, in ki so torej povezane $\mathrm{z}$ razvojem njihovih kompetenc. Pri izvajanju Zoisovega štipendiranja morajo sodelovati vsi trije podsistemi: a) vzgojnoizobraževalne organizacije, kjer poteka zgodnejše odkrivanje in delo z nadarjenimi učenci, b) podporno okolje $\mathrm{v}$ času srednješolskega in visokošolskega izobraževanja in c) delodajalci, ki izkazujejo interes za zaposlitev Zoisovih štipendistov. Pogoj za uspešno izvedbo reforme Zoisovega štipendiranja je tudi ustanovitev posebnega sklada za Zoisove štipendije, ki bo na državni ravni povezal vse tri podsisteme. Potrebno je izboljšati merila za izbor Zoisovih štipendistov in jih predhodno empirično preveriti, določiti dodatne obveznosti Zoisovih štipendistov med šolskim ali študijskim letom in spodbuditi njihovo vključevanje $\mathrm{v}$ dodatne, ustvarjalne aktivnosti na področju izražene nadarjenosti (talenta), istočasno pa spodbuditi razvoj različnih oblik dodatnih (šolskih in izvenšolskih) dejavnosti, ki so v funkciji razvoja nadarjenosti ter omogočiti povezovanje Zoisovih štipendistov z zainteresiranimi delodajalci že $\mathrm{v}$ času izobraževanja. Financiranje dodatnih aktivnosti Zoisovih štipendistov bi lahko potekalo v obliki vavčerjev, za kar bi namenili ustrezen delež Zoisove štipendije (ki jo lahko štipendist izrabi po svoji želji), drugi del pa dobi štipendist izplačan v denarju kot do sedaj. Na ta način bi se zagotovila namenska poraba štipendije v funkciji razvoja nadarjenih. Zoisove štipendije bi tako postale privlačne za tiste nadarjene, ki se želijo izpopolnjevati in imajo močno notranjo motivacijo, kar v sedanjih določilih ZŠtip-1 ni omenjeno. Spodbujanje lastne aktivnosti na področjih, ki posameznika zanimajo, predstavlja naložbo v razvoj nadarjenih, hkrati pa se spodbuja povezovanje Zoisovih štipendistov s potencialnimi delodajalci, s čimer se štipendistom omogoča lažji prehod v ustrezno zaposlitev. To pa je namen, ki jih dosedanji sistemi Zoisovega štipendiranja niso izpolnjevali, še posebej ne sistem Zoisovih štipendij po letu 2008. 


\section{Literatura}

Bevc, M. (2007). Človeški viri v razvojno-raziskovalni dejavnosti v Sloveniji v zadnjih 15 letih in primerjava $\mathrm{z}$ državami EU [Human resources in research and development activity in Slovenia in the last 15 years and comparison with EU countries]. IB revija, 41(1), 56-72.

European Commission (2003). Third European report on science \& technology indicators (str. 179). Bruselj, Belgija: Directorate-General for Research Information and Communication Unit. Dostopno na: ftp://ftp.cordis. europa.eu/pub/indicators/docs/3rd_report.pdf

Gabršček, S. (2004). Evalvacijska študija Zoisovih štipendij[Evaluation study of the Zois scholarships]. Ljubljana, Slovenija: Center za promocijo znanja.

Gagné, F. (2008). Building gifts into talents: Briefoverview od the DMGT. Dostopno na: http://nswagtc.org.au/images/ stories/infocentre/dmgt_2.0_en_overview.pdf

Heller, D. E. in Marin, P. (ur.). (2002). Who should we help? The negative social consequences of merit scholarships. Cambridge, MA, ZDA: The Civil Rights Projects at Harvard University.

Holland, J. (1997). Making vocational choices: A Theory Of Vocational Personalities And Work Environments (3. izd.). Odessa, FL, ZDA: Consulting Psychologists Press.

Juriševič, M. (2012). Motiviranje učencev v šoli [Motivating students in school]. Ljubljana, Slovenija: Pedagoška fakulteta.

Kogej, P. (1996). Milijoni za talente [Millions for the talented]. V J. Zalaznik (ur.), Zbornik strokovnih prispevkov o štipendiranju nadarjenih 1986-1996 [Proceedings of expert contributions on scholarships for the talented 1986-1996] (str. 39-44). Ljubljana, Slovenija: Republiški zavod za zaposlovanje.

Makarovič, J. (1984). Družbena neenakost, šolanje in talenti [Social inequality, education and the talented]. Maribor, Slovenija: Obzorja.

Makarovič, J. (1990). Kreativnost in odkrivanje nadarjenih: Izdelava instrumentarija za odkrivanje nadarjenih - Vpliv družbenega in fizičnega okolja na razvoj kreativnosti mladih [Creativity and discovering talent: Construction of instruments for talent detection - Impact of social and physical environment on the development of the creativity of young people]. Ljubljana, Slovenija: Raziskovalni inštitut FSPN.

Makarovič, J. (1996). Odkrivanje talentov: Iz preteklosti v prihodnost [Discovering Talent: From past to future]. V J. Zalaznik (ur.), Zbornik strokovnih prispevkov o štipendiranju nadarjenih 1986-1996 [Proceedings of expert contributions on scholarships for the talented 1986-1996] (str. 4-30). Ljubljana, Slovenija: Republiški zavod za zaposlovanje.

Merljak, S. (2014, 8. oktober). Zoisove štipendije za študente in zgodba neke absolventke [Zois scholarships for students, and the story of a final year student]. Delo. Dostopno na: http://www.delo.si/znanje/izobrazevanje/zoisovestipendije-za-studente-in-zgodba-neke-absolventke.html

Ministrstvo za visoko šolstvo, znanost in tehnologijo. (2007). Resolucija o Nacionalnem programu visokega šolstva Republike Slovenije 2007-2010 [Resolution on the National Programme of Higher
Education of the Republic of Slovenia 2007-2010]. Ljubljana, Slovenija: Avtor. Dostopno na: http://www. uni-lj.si/mma/20070118RNPVS/2013070110010162/

Mlakar, P. (2012, 12. julij). Lažje do zadetka na lotu kot do Zoisove štipendije: Če mladi kljub nadarjenosti štipendije ne dobijo, se to pozna na njihovi samopodobi in učni uspešnosti [Easier to hit the lottery than the Zois scholarship: When young talents don't get grants it lowers their self-esteem and academic achievement]. Dnevnik. Dostopno na: https://www.dnevnik.si/1042541243

Nagy, M. (2005). Zoisove štipendije - 18 let odkrivanja talentov [The Zois scholarships - 18 years of discovering talents]. V M. Vizjak Pavšič, M. Salobir in M. Jeraj (ur.), Inteligentnost, ustvarjalnost, nadarjenost: Zbornik razprav 5: Dnevi slovenskih psihologov, Bled, 16. in 17. april 2004 [Intelligence, creativity, talent: Proceedings 5: Days of Slovenian psychologists, Bled, 16th and 17th April 2004] (str. 57-90). Ljubljana, Slovenija: Društvo psihologov Slovenije; Velenje, Slovenija: Gorenje, d.d.

Nagy, M. (2006). Analiza meril v šolskem letu 2005/06 (interno delovno gradivo) [Analysis of the criteria in the school year 2005/06 (internal working materials)]. Ljubljana, Slovenija: Zavod Republike Slovenije za zaposlovanje.

Pivec, F. (1989). Dograjevanje sistematičnega dela $\mathrm{Z}$ nadarjenimi učenci in študenti [Upgrading the systematic work with gifted pupils and students]. V J. Zalaznik (ur.), Štipendiranje in nadarjenost [Scholarships and giftedness] (str. 45-60). Ljubljana, Slovenija: Republiški zavod za zaposlovanje .

Pravilnik o dodeljevanju Zoisovih štipendij [Rules on the allocation of the Zois scholarships]. Uradni list RS, št. 51/08 (2008). Dostopno na: https://www.uradni-list. si $/ 1 /$ content?id $=86675$

Pravilnik o spremembah in dopolnitvah pravilnika o štipendiranju [Rules amending the Rules on Scholarships], Uradni list RS, št. 39/1997 (1997). Dostopno na: http:// www.uradni-list.si/1/index?edition=199739\#!/Uradnilist-RS-st-39-1997-z-dne-30-6-1997

Pravilnik o štipendiranju (neuradno prečiščeno besedilo) [Rules on scholarships (unofficial consolidated text)], Uradni list RS, št. 8/1999, 43/2000, 62/2001, 85/2002, 15/2003 - odl. US, 40/2003, 64/2004, 28/2006, 50/2006, 80/2006, 57/2007 (1999). Dostopno na: http://www. mddsz.gov.si/fileadmin/mddsz.gov.si/pageuploads/ dokumenti__pdf/p_stipendiranje_57_07_npb.pdf

Stanovnik, P. (2008). Tehnološka predvidevanja in slovenske razvojne prioritete: Končno poročilo: II. faza [Technologicalassumptionsand Sloveniandevelopmental priorities: Final Report: Phase II]. Ljubljana, Slovenija: Inštitut za ekonomska razsikovanja, Fakulteta za management Primorska univerza, Fakulteta za družbene vede Univerza v Ljubljani. Dostopno na: http://www. mgrt.gov.si/fileadmin/mgrt.gov.si/pageuploads/DPK/ CRPi_2006/CRP_V5-0223_Tehnolosko_predvidevanje_ in_slovenske_razvojne_prioritete.pdf

Statistični urad RS. (2015). Štipendisti, Slovenija, šolsko/ študijsko leto 2014/15 [Scholarship recipients, Slovenia, school/academic year 2014/15]. Ljubljana, Slovenija: Avtor. Dostopno na: http://www.stat.si/StatWeb/prikazinovico $\mathrm{id}=5476 \& \mathrm{idp}=9$ \&headerbar $=7$ 
Stergar, E. (1988). Štipendisti "generacije 1976" [Scholars of "Generation 1976"]. V E. Stergar (ur.), Proučevanje studijske poti študentov v SRS: Generacija 1976 [Examining the study path of students in SRS: Generation 1976] (str. 491-495). Ljubljana, Slovenija: Center za razvoj univerze.

Študentska organizacija Slovenije (ŠOS). (2012). Predlog zakona o štipendiranju [A bill on scholarships]. Ljubljana, Slovenija: Avtor. Dostopno na: http://www.studentskaorg.si/dokumenti/SOSPredlogZstip.pdf.

Toličič, I. in Zorman, L. (1977). Okolje in uspešnost učencev: Vpliv socialnoekonomskih in demogeografskih dejavnikov na šolski uspeh in osebnostne lastnosti otrok [Environment and academic achievement: The impact of demographic and socioeconomic factors on academic achievement and personality traits of children]. Ljubljana, Slovenija: Državna založba Slovenije.

Univerza v Novi Gorici. (2014). Naslovi predavanj, delavnic in naravoslovnih dni, ki jih organiziramo za srednje šle [The titles of lectures, workshops and science days, which are organized for secondary schools]. Nova Gorica: Avtor. Dostopno na: http://www.ung.si/media/ storage/cms/attachments/2015/02/04/07/57/07/Naslovi_ predavanj_in_teme_delavnic_2014_15.pdf

Zakon o štipendiranju (ZŠtip) [Scholarship Act], Uradni list RS, št. 59/07 (2007). Dostpno na: http://www.uradni-list. si/1/content?id=81089

Zakon o štipendiranju (ZŠtip-1) [Scholarship Act], Uradni list RS, št. 56/13 (2013). Dostopno na: https://www.uradnilist.si/1/content?id $=113765$

Zalaznik, J. (1989a). Štipendiranje učencev in študentov z izrazito nadpovprečnimi uspehi [Scholarships for pupils and students with highly above-average success]. V J. Zalaznik(ur.), Štipendiranje in nadarjenost [Scholarships and giftedness] (str. 7-9). Ljubljana, Slovenija: Republiški zavod za zaposlovanje.

Zalaznik, J. (1989b). Iz izkušenj prvega leta: Brez sprememb $v$ naslednjih dveh letih [From the experience of the first year: No change in the next two years].V J. Zalaznik (ur.), Stipendiranje in nadarjenost [Scholarships and giftedness] (str. 38-46). Ljubljana, Slovenija: Republiški zavod za zaposlovanje.

Zalaznik, J. (1996). Štipendiranje talentov: Drugič [Scholarships for the talented: Part II]. V J. Zalaznik (ur.), Zbornikstrokovnih prispevkovo štipendiranjunadarjenih 1986-1996 [Proceedings of expert contributions on scholarships for the talented 1986-1996] (str. 31-38). Ljubljana, Slovenija: Republiški zavod za zaposlovanje.

Žišt, F. (2014, 9. avgust). Športniki se z izločitvijo ne strinjajo [Athletes against the elimination]. Večer. Dostopno na: http://www.vecer.com/clanek2014080906050593 